\title{
Recent Progress of Nanocarrier-Based Therapy for Solid Malignancies
}

\author{
Qi-Yao Wei ${ }^{+}{ }^{+}$, Yan-Ming $\mathrm{Xu}^{+}+\mathbb{( 1 )}$ and Andy T. Y. Lau *(i) \\ Laboratory of Cancer Biology and Epigenetics, Department of Cell Biology and Genetics, Shantou University \\ Medical College, Shantou 515041, Guangdong, China; 19qywei@stu.edu.cn (Q.-Y.W.); \\ amyymxu@stu.edu.cn (Y.-M.X.) \\ * Correspondence: andytylau@stu.edu.cn; Tel.: +86-754-8853-0052 \\ + These authors contributed equally to this work.
}

Received: 27 July 2020; Accepted: 21 September 2020; Published: 28 September 2020

Simple Summary: Although conventional anti-cancer drugs have been the footstone in the fight against cancer, yet they are far from optimal due to issues related with indiscriminate destruction of normal cells, multidrug resistance, and toxicity, as a result, a more selective therapy is urgently needed. Nanocarriers have been increasingly used in drug delivery, especially in cancer therapy. Nanocarriers can improve the therapeutic effect of drugs in cancer by enhancing the specificity and prolonging the circulating half-life of drugs. The aim of this review is to offer a detailed description of different cytotoxic drug nanocarriers and their recent progress. It is expected that this review will be of help to those who have been seeking new study directions in this field and also ones who are about to start the research on nanocarrier-based drug delivery.

\begin{abstract}
Conventional chemotherapy is still an important option of cancer treatment, but it has poor cell selectivity, severe side effects, and drug resistance. Utilizing nanoparticles (NPs) to improve the therapeutic effect of chemotherapeutic drugs has been highlighted in recent years. Nanotechnology dramatically changed the face of oncology by high loading capacity, less toxicity, targeted delivery of drugs, increased uptake to target sites, and optimized pharmacokinetic patterns of traditional drugs. At present, research is being envisaged in the field of novel nano-pharmaceutical design, such as liposome, polymer NPs, bio-NPs, and inorganic NPs, so as to make chemotherapy effective and long-lasting. Till now, a number of studies have been conducted using a wide range of nanocarriers for the treatment of solid tumors including lung, breast, pancreas, brain, and liver. To provide a reference for the further application of chemodrug-loaded nanoformulations, this review gives an overview of the recent development of nanocarriers, and the updated status of their use in the treatment of several solid tumors.
\end{abstract}

Keywords: nanotechnology; drug delivery; solid tumor therapy; drug resistance

\section{Introduction}

Chemotherapy, the use of cytotoxic drugs in their free form to kill cancer cells or inhibit cancer cell division, remains the mainstay of treatment for solid tumors, majorly in cases of cancer of the lung, breast, brain, liver, and pancreas. Although antineoplastic drugs have improved patient survival and treatment outcomes, their treatments are not effective enough stems from non-specific toxicity, high metabolism, and unfavorable pharmacokinetics [1-3]. Adverse effects will continue to occur in the form of induction of multidrug resistance and low survival profile of patients. Owing to these threats, nanocarriers have been attempted for cancer therapy as quite encouraging systems. Antineoplastics 
can be entrapped within, physically adsorbed, or form chemically covalent bonds on the surface of the nanocarrier [4].

Nanomedicines have been a highly active field, as exemplified by the steadily-increasing number of articles reporting on nanocarriers for drug delivery (Figure 1). The nanotechnology-based novel drug delivery system (DDS), to some extent, can overcome the above-mentioned drawbacks of chemotherapy drugs mainly based on two mechanisms: Passive and active targeting. Their application as successful drug-carrier for chemotherapeutic drugs in cancer treatment is primarily related to their size, higher surface area to volume ratio, shape, charge, and composition [5]. Certain sized drug-loading particles tend to accumulate in tumor tissue much more than they do in healthy tissues, namely "passive targeting" [6]. Nanosize of NPs enables them to specifically accumulate inside the tumor through enhanced permeability and retention effect (EPR) characteristic of tumors. EPR is based on aberrant pathophysiological characteristics of tumors [7]. The presence of irregular, fenestrated blood vasculature and diminished lymphatic drainage results in the extravasation of NPs from the circulation into the tumor rather than the surrounding healthy tissue and prevented clearance of NPs, leading to their accumulation in the tumor tissue [8]. In other words, the high permeability of the tumor vasculature makes it easier for large molecules and NPs to enter. At the same time, tumor tissues generally lack effective lymphatic drainage, therefore allowing NPs to accumulate there. In order to enhance passive accumulation in the tumor site, the common method is to modify the size or shape of NPs. However, the efficiency of passive targeted delivery is very low, with less than $1 \%$ of nanotherapeutic drugs found in tumors [9]. When passive targeting is insufficient, the active targeting can be attained by conjugation of the NPs with targeting ligands (e.g., antibodies or peptides), or through the use of an external stimulus to the desired location [10]. Conjugation of NPs with ligands not only facilitates accumulation in the interstitial space of the tumor, but also receptor-mediated endocytosis leads to the internalization of NPs, providing further opportunities for the release of targeted drugs [11]. Active targeting has more potential than passive targeting strategies, due to it ideally allowing for cell-specific killing of not only primary tumor cells but also of metastatically spread circulating cancer cells $[12,13]$. Currently, active targeting NPs are supported as a favorable complementary strategy to EPR to further enhance the efficiency of nanodrugs. Stimuli-regulated release NPs systems have been designed to respond to different types of stimuli. The stimuli can be characteristic of the pathological site (internal stimuli), and stimuli-regulated release NPs systems are achieved through the inclusion of components that react to abnormal $\mathrm{pH}$, temperature, and redox conditions, and to the overexpression of certain biological molecules. The NPs systems can also respond to stimuli from outside the body, such as light, ultrasound, and microwaves [14]. These nanomedicines are essentially a multicomponent system, including well-defined nanostructures as delivery vehicles, one or more drugs as a therapeutic agent, and bioactive moieties to extend half-life and promote accumulation in the target site. Thus, the multicomponent system can increase the effective concentration of chemotherapy drugs in tumor cells as well as minimize the risk of resistance. 


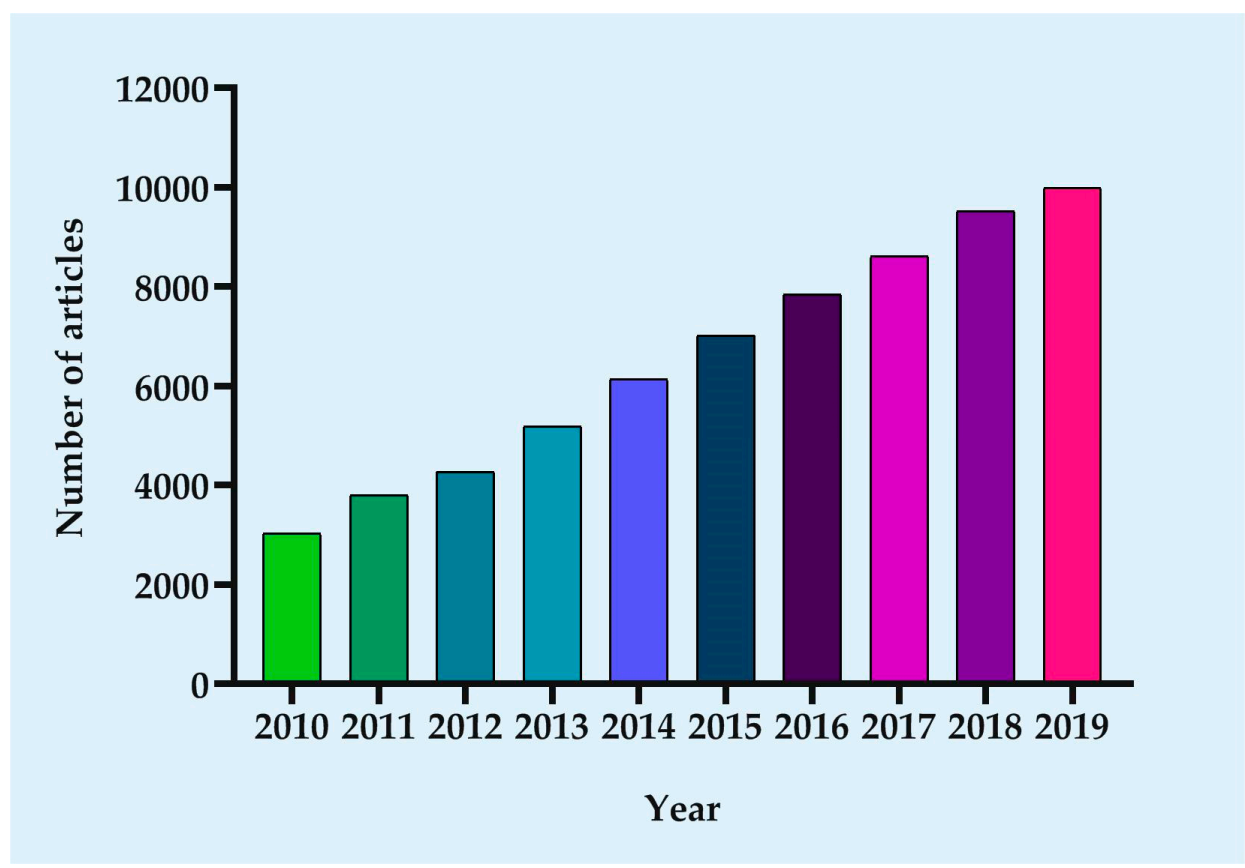

Figure 1. Growth in the number of published articles. Since the focus of this paper is on nanocarrier-based drug delivery for cancer therapy, the following parameters were searched in PubMed: ((cancer) OR (tumor)) AND ((((()(((((((nanoparticle) OR (nanocarrier)) OR (liposome)) OR (micelles)) OR (dendrimers)) OR (Niosomes)) OR (nanoemulsions)) OR (nanocrystals)) OR (Exosomes)) OR (quantum dots)) OR (carbon nanotubes)) OR (nanodiamonds)) OR (nanocapsules)) OR (hybrid nanomedicine)).

In this review, we outline the varied architectures of nano-systems and the recent development of nanotechnology in the field of solid tumor treatment. Focusing the direction of this field will help to develop new therapeutic strategies and improve the therapeutic outcome of solid tumors.

\section{Development of Nano-Sized Delivery Systems for Solid Cancer Therapy}

\subsection{Liposomal Nanocarriers}

Among the nanocarriers used to treat cancer, lipid-based nanocarriers have made great progress. There are currently different types of lipid-based formulation, such as liposome systems, solid lipid NPs (SLNs), and nanostructured lipid carriers (NLCs). These lipid-based systems tend to be less toxic than other DDSs, such as polymer NPs, because of their biocompatibility and biodegradability.

Liposomes are artificially-generated spherical drug carrier vehicles composed of a lipid bilayer surrounding a hollow core into which chemotherapeutic drugs can be loaded for delivery to tumors sites $[15,16]$. The assembly of liposomes is fairly straightforward because the amphiphilic nature of the phospholipid and the thermodynamic properties of the water environment drive the self-assembly into an entropically favorable direction, with a hydrophobic segment enclosed within the NP core [17]. By far, liposomes have been the most successful formulation for clinical application [18]. The bilayer structure of liposomes can be composed of natural phospholipids, cholesterol, etc., making them ideal carriers for different drugs of varying solubility, as hydrophilic molecules can be incorporated within the core (e.g., Doxil ${ }^{\circledR}$, encapsulated doxorubicin (DOX)) while hydrophobic drugs can be housed within the lipid membrane [19]. Thus, liposomes can carry both water-soluble and poorly soluble drugs to a target site. Beyond that, they possess low immunogenicity, low toxicity, and drug protection. To increase circulation time, biocompatible and inert polymers such as polyethylene glycol (PEG) are added to the surface of liposomes, forming a protective layer, which prevents the clearance of the reticuloendothelial system. 
SLNs are nanosized lipid-based colloidal carrier systems, combining the advantages of colloidal counterparts (e.g., polymeric NPs, liposomes, and nanoemulsions) [20]. Some areas where SLNs perform better than their counterparts, like economical large-scale production, long-term stability, and controlled drug release [21]. SLNs are the most common method to improve the oral bioavailability of water-soluble drugs. However, the SLNs system is limited by the low drug loading compared with other nanosystems.

NLCs are the second generation of SLNs, which are a mixture of different lipids, i.e., solid lipid matrix with a certain content of a liquid lipid. NLCs have greater drug loading than SLNs, as many drugs have different solubility in solid and liquid lipids. Increasing the liquid-fat quality may increase the solubility of drugs and improve the encapsulation efficiency of lipid carriers [22,23]. NLCs showed a lower risk of gelation and drug leakage, it can also prolong the half-life of drugs, enhance the EPR effect, subsequently improves the therapeutic effect of anti-tumor drugs.

\subsection{Micelles}

Micelles are another type of lipid nanostructure and are defined as a collection of amphiphilic surfactant molecules that spontaneously aggregate in water into a (usually) spherical vesicle [24]. Micelles have hydrophilic heads that form the outer shell, and hydrophobic tails forming the interior that can protect hydrophobic drugs from the external environment [25]. The hydrophobic/hydrophilic structural characteristics of micelles have attracted attention as a DDS, particularly in improving the bioavailability of low water-soluble drugs. However, poor chemical versatility and structural instability are obstacles to their application.

\subsection{Polymeric Micelles (PMs)}

PMs, consist of a hydrophilic shell and a hydrophobic core, which are self-assembled core-shell constructs in selective solvents [26]. The hydrophobic core of PMs can accommodate large amounts of hydrophobic drugs at higher concentrations, while shell not only provides steric stability of nanostructured micelles, but also facilitate their functionalization, allowing the drugs to be delivered to the target site by controlling $\mathrm{pH}$, temperature, and ultrasound, and decorating with peptides or antibodies [27]. Their major advantage over micelles is their great chemical versatility that allows for controlling and modulating both chemical and structural features to improve drug loading capacity as well as drug target specificity [25]. As the carrier of hydrophobic anticancer drugs, PMs are characterized by high drug encapsulation rate, long drug retention time in blood, increased drug permeability, and strong tumor penetration [28].

\subsection{Polymer-Based Nanocarriers}

Polymeric NPs are colloidal systems. They are organic polymer compound assemblies in the form of nanospheres (solid spheres) or nanocapsules (hollow spheres with a void space in the center) $[29,30]$. They can be composed of natural polymers (e.g., chitosan, hyaluronic acid (HA), cellulose, and corn starch), synthetic polymers (e.g., polyvinyl alcohol (PVA), PEG, and poly (lactic-co-glycolic acid) (PLGA)) [31,32]. The core-shell structure of polymeric nanosystems facilitates the encapsulation of hydrophobic drugs, extends circulation time, and controls drug release. The tight assembly of the outer particle layers in the polymerized nanocapsules allows better retention of the drug and thus enhanced delivery to the tumor site. The physicochemical characteristics of the polymer (e.g., surface charges, size, shape, flexibility, and length of the main carbon chain) can also be easily engineered to achieve high biodegradability, high content of drug loads, and target tumor locations [33,34]. However, polymer NPs also have some disadvantages, such as residual organic solvents in the preparation process, difficulty in large-scale industrial production, and polymer cytotoxicity. 


\subsection{Dendrimers}

Dendrimers, normally 1-10 $\mathrm{nm}$ in diameter, are chemically synthesized highly branched polymers with a highly symmetric spherical shape [35]. Usually, they are produced from natural or synthetic ingredients, including sugars, nucleotides, and amino acids. Drugs could be entrapped in the dendrimer core by hydrogen bonds, electrostatic or hydrophobic interactions. Besides, hydrophobic or hydrophilic anticancer drugs can also be covalently attached to the surface of dendrimers. When the drug is attached to many peripheral groups of a dendrimer, it will result in the enhanced solubilization of the drugs, the amplified effective concentration of the drugs at the target site, and the controlled release of the drugs depending on the linkers used [36]. The structure of low-generation dendrimers is usually flexible and open, while high-generation dendrimers are dense and globular [37]. Dendritic polymers are easy to be functionalized and have unique advantages, including high stability, water-solubility, decreased immunogenicity, and antigenicity, which make them an attractive drug delivery carrier. Despite these promising characteristics, dendrimers share a limiting feature with polymer therapeutics: The multistep synthesis that increases production costs [38].

\subsection{Niosomes}

Niosomes, non-lecithin carriers, have a similar structure to liposomes but they are more stable [39]. They are vesicle systems synthesized by nonionic surfactants with some advantages, such as biodegradability, biocompatibility, and encapsulation of both lipophilic and hydrophilic drugs [40]. They were designed to overcome the limitations of liposomes, especially those associated with phospholipid oxidation. At the same time, niosomes have lower manufacturing costs and longer shelf life, and their bilayer fluidity and microviscosity could be easily regulated. $\mathrm{pH}$ (Low) insertion peptide (pHLIP)-coated niosomes were successfully developed by Pereira et al. [41]. Compared with pHLIP-coated liposomes, pHLIP-coated niosomes are smaller and more stable, with $\mathrm{pH}$-dependent cell uptake and excellent tumor targeting. Therefore, niosomes loaded with lipophilic and/or hydrophilic drugs can effectively enter into cells in a pH-dependent manner. The versatility of niosomes enhanced drug oral absorption. On the other hand, the encapsulation ability of niosome is relatively low, thus different surfactant combinations are needed to encapsulate various hydrophobic molecules in its bilayer membrane, so as to maintain the overall stability of the nanovesicles.

\subsection{Nanoemulsions}

Nanoemulsions are made of oil, water, emulsifier, and co-emulsifier in proper proportion, and the particle size is 10-100 $\mathrm{nm}$ diameter [42]. Nanoemulsions have been widely studied as drug carrier of lipophilic chemotherapeutics, due to its biodegradability, easy preparation, and controllable drug release $[43,44]$. Besides, nanoemulsions not only can avoid drug inactivation in the gastrointestinal tract but also increase the solubility of the drugs so that the drugs can be well dispersed and absorbed, so as to improve the bioavailability of drugs. Nanoemulsions also has good biocompatibility due to the incorporation of a generally recognized as the safe grade of excipients, in which the entrapment efficiency of the hydrophobic components is high, showing physicochemical stability and improved bioavailability with superior efficacy and safety.

\subsection{Nanocrystals}

Nanocrystals are referred to as pure solid particles with the character of the crystal [45]. Some poorly soluble drugs have been salvaged through formulating nanocrystal. Nanocrystals possess unique traits such as the increased surface area to volume ratio, steady dissolution rates, enhanced structural stability, and high drug-loading efficiency, due to nanocrystals consisting of entirely of the drug or payload, thereby eliminating the ancillary role of a carrier and resulting in satisfactory therapeutic concentrations at low dose [46]. Nanocrystals were originally used to enhance the oral bioavailability of low-soluble drugs. To date, although researches on the drug nanocrystal in cancer treatment are still at 
the preclinical animal level, nanocrystal formulation has gained wide concern for intravenous delivery of anticancer drugs $[45,47]$. Due to rapid ingestion by macrophages, intravenous nanocrystals can be passively transported to mononuclear phagocytic system cells rich organs such as the liver, spleen, and lungs [48]. The particle size, morphology, and surface modification of nanocrystals have a great influence on their distribution in vivo. The size, stability, solubility, and bioavailability of nanocrystals are often affected by the $\mathrm{pH}$ of the dispersed medium, impurities formed during manufacturing, as well as the crystallinity [46].

\subsection{Bio-NPs}

Due to good biocompatibility, better stability, and biodegradability, nanostructures with biological materials have become a powerful platform for drug delivery [49]. However, the synthesis strategies of bio-NPs could sometimes be complex, resulting in increased cost and manufacturing time. Therefore, more researches are needed to explore the manufacture of these bio-NPs from lab-scale to commercial industrial scale. Viral NPs obtained from viruses and bacteriophages have attracted considerable interest for drug delivery due to their flexibility in sizes and shapes, biocompatibility, and easy surface modification [50].

Nanocarriers synthesized by synthetic polymers at times cause high residue of solvents and surfactants, which may limit their efficacy and induce toxicology issues. In this regard, protein-encapsulated nanocarriers, prepared from animal-based protein (e.g., albumin, collagen, and gelatin) or plant-based protein (e.g., ferritin), have been recently investigated for the drug delivery [51]. Protein-based nanocarriers have several advantages in drug delivery, such as good biodegradability, easy surface modification ability, no immunological responses, and low toxicity. Specifically, the application of albumin-based NPs in the biomedical field has been studied since 1972 [52]. The first protein-based NP approved by the U.S. Food and Drug Administration (FDA) is Abraxane ${ }^{\circledR}$, albumin-bound paclitaxel (PTX) NP formulation, used in combination with chemotherapy drugs to treat a variety of cancers. However, protein drugs usually have pharmacokinetic and pharmacological defects, such as instability, short half-life, and sometimes low water solubility. The protein conjugated with a biologically inert polymer is a good manner to improve its chemical stability while maintaining the biological function. Apoferritin (APO), the hollow protein nanocage, undergoes a process of assembly and disassembly with the change in $\mathrm{pH}$ after the iron core is removed and is extensively used to synthesize various NPs for cancer treatment [53].

\subsection{Exosomes}

Exosomes, nanometer-sized extracellular vesicles, are secreted by all types of cells and can also be found in various body fluids [54]. Water-soluble drugs can be stored by the hydrophobic core of exosomes, which are therefore emerging as a promising natural vehicle for drug delivery. Also, exosomes exhibit a natural targeting capacity, high stability, high capacity to pass through various biological barriers, and are less immunogenic than artificial drug carriers, probably due to their small size, and they are isolated from the patient's cells [55]. Exosomes provide a more stable environment for therapeutic drugs, and their components, cargo, and targeting ability can be further enhanced by conditioning parental cells or adding functional drugs that improve their natural potential, thus giving them additional functions [56]. Even though there are many advantages of exosomes, there are several important obstacles to overcome before clinical application. Natural exosomes are complex structures, making the identification of them difficult [57]. In addition, exosomes may contain inherently numerous bioactive molecules. If the alteration of the exosomes' cargo is required, it is important to use specific approaches to load the desired additional drugs without disturbing the exosomes, as damaged exosomes with no exosomal signals may lead to undesirable immune responses [58]. Understanding the function and structure of exosomes will contribute to the clinical setting of exosome therapy [59]. 


\subsection{Inorganic NPs}

Inorganic NPs, which refer to nanocarriers synthesized by metal and semi-metal materials, have gained increasing interest in the recent past. Due to easily scalable synthesis, simplified modification of targeting molecules, high stability, controlled release of the drug, and capability of facilitating targeted drug delivery with imaging possibilities, inorganic nanomedicines have been studied to find a nanocarrier for delivering chemotherapeutic drugs. Among various inorganic NPs, metal NPs (e.g., gold, silver, ZnO), silica NPs (SiNPs), selenium NPs (SeNPs), magnetic NPs (MNPs), quantum dots (QDs), carbon nanotubes (CNTs), and nanodiamonds (NDs), were widely investigated in cancer treatment.

Many NPs, such as QDs, metal NPs, ceramic NPs, oxide NPs, are difficult to produce in aqueous media or require multiple processes and difficult to control reactions, so consistency in products is not always guaranteed. Au NPs, an attractive challenger in cancer therapy, possess unique properties including ease of production and functionalization, and high biocompatibility. Silver is usually a non-toxic, hypoallergenic metal with the ability to protect cells and promote healing, and has recently attracted attention as a nanocarrier. In cancer cells, AgNPs induce the ROS generation, which results in inflammatory responses and subsequently mitochondrial destruction. Further apoptogenic factors are excluded leading to the death of cancer cells $[60,61]$. The toxicity of NPs can be overcome by synthesizing NPs by the biological method and coating the surface of NPs with the degradable non-toxic polymer.

SiNPs have a significant advantage in oral administration. In the complex gastrointestinal environment, SiNPs can both protect hydrophobic drugs from the intestinal milieu and be resistant to low $\mathrm{pH}$. In addition to non-porous SiNPs, porous SiNPs characterized by adjustable pore size, ordered pore structure, high pore volume, low-pH tolerance, high thermal stability, and large surface area for functionalization, which has attracted extensive attention. Mesoporous SiNPs (MSNs) are efficient systematic DDS due to the high amount of drug loading capacity, a strong affinity for head groups of different phospholipids, high cellular penetrations, protection of the water-insoluble drug at therapeutic levels, and sustained release at the targeted delivery site. Studies have proven that MSNs can be endocytosed by cancer cells, non-cancer cells, or macrophages.

SeNPs have attracted wide attention as potential chemotherapeutic carriers because selenium is a trace element and plays an important role in cancer prevention [62-64]. In addition, selenium facilitates drug toxicity reduction, the regulation of the function of the thyroid gland and the immune system, thus plays a strong part in fighting disease. However, the absence of active targeting capability is still a problem to be solved.

MNPs are a class of nanoscale carriers containing iron oxide. The discovery of MNPs has attracted considerable research interest, primarily because of their ability to perform multiple functions simultaneously, such as colloidal carriers that can target drugs to tumor sites with real-time monitoring. The simplest form of drug delivery of MNPs consists of an inorganic material core and a decorated surface coating to enhance stability and biocompatibility under the physiological environment.

QDs are a kind of tiny inorganic semiconductor nanocrystals with a diameter of 1-10 nm. Due to its unique surface chemistry available for modification and multi-wavelength luminescence characteristics of high luminous stability, they have attracted much attention in tumor research and become an ideal material for targeted drug delivery [65]. The general structure of QDs is composed of a semiconductor core, coated with a shell to change its physical and chemical properties and improve solubility [66]. However, the major disadvantages of QDs are its toxicity and excretion pathway. Researches have shown that their toxicity depends largely on their core-shell materials, bioconjugation, and surface functionalization.

CNTs are carbon allotropes that are insoluble in water and other organic solvents, and their toxicity in biological liquids is a key limiting factor. However, they can be transformed into water-soluble nanocarriers by chemical modification to improve their biocompatibility and reduce toxicity. The material has unique physicochemical properties, as the hollow monolithic structure that 
can accommodate high payload and the ability to add any functional groups, making them a suitable and effective delivery system for chemotherapeutic agents [67].

NDs include unique electrostatic properties, a chemically inert core, scalable processing and synthesis parameters, and an adjustable surface resulting in a simple mechanism of drug deposition [68]. NDs as drug carriers have attracted much attention, due to the facile nature of functionalizing their surfaces with chemotherapeutic drugs, especially anthracyclines. The drugs can be both covalently or noncovalently attached to NDs [69].

Certain other inorganic NPs, such as bismuth, barium, calcium, magnesium, copper, nickel, and titanium dioxide, are also used in the treatment of cancer [70]. The main risk of these inorganic NPs is toxicity, which is closely related to the size control, shape regulation, surface modification, concentration, and time of exposure. The precise control of these physicochemical parameters can promote their meaningful application in cancer therapy. Nonetheless, clinical translation of these nanomaterials is still not extensive compared to other counterparts, due to a lack of understanding of their long-term toxicity, pharmacokinetics, pharmacodynamics, and degradability.

\subsection{Hybrid Nanomedicines}

Hybrid nanomedicines are a mixture of inorganic and organic ingredients that enables the desired hybrid nanomaterial formulation and allows the system to change to achieve the desired results. Current researches focus on the mixing of polymer and liposome systems. The resultant structures, known as polymer-lipid hybrid NPs (PLNs), are characterized by particle sizes less than $100 \mathrm{~nm}$ in diameter. The core of PLNs is a polymer-drug complex and the increasing number of bio-polymers offers a number of opportunities for drug conjugation. The outer shell of PLNs is composed of lipid, which contributes to their high biological compatibility [71]. Thus, PLNs combine the biomimetic properties of liposomes with the sturdiness of biodegradable polymers, which display high structural integrity, controllable drug release, and the possibility of binding to targeted delivery factors.

Lipid nanocapsules (LNCs) consist of a liquid oily core and a shell of surfactants, as a hybrid between polymeric nanocapsules and liposomes [72]. The LNCs can contain comparatively high concentrations of liposoluble drugs in their liquid oily core. Unlike earlier nanocarriers, LNCs are obtained with pharmaceutically acceptable excipients based on a solvent-free soft-energy procedure. Moreover, LNCs have a high drug-loading capacity and physical stability, and a sustained drug release pattern [73]. In a word, LNCs are promising nanocarriers for drug delivery.

Metal-organic frameworks (MOFs, also known as porous coordination polymers), a unique class of hybrid porous materials, which have attracted significant research interest in biomedical application. MOFs are built from metal ions and organic linkers [74,75]. Due to their chemical versatility, enormous porosity, high drug loading, and tunable degradability, nanoscale MOFs have been adopted as promising carriers for therapeutic drugs [76,77].

Schematic representation of the commonly used as nanocarrier types were showed in Figure 2. Summary of types of NPs and their advantages and disadvantages were included in Table 1. 


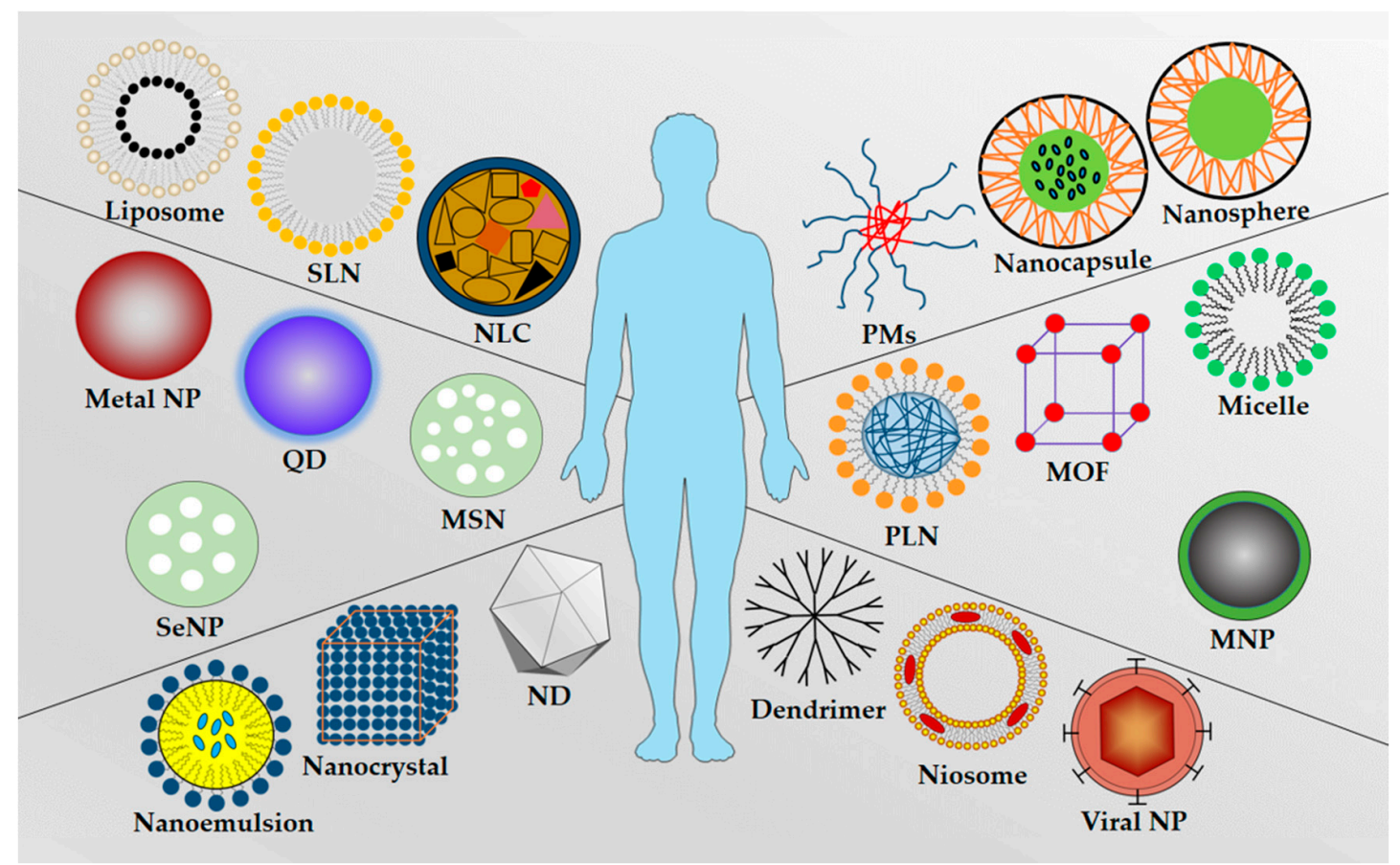

Figure 2. Schematic representation of the commonly used nanocarrier types: Liposome, solid lipid nanoparticle (SLN), nanostructured lipid carrier (NLC), polymeric micelles (PMs), nanocapsule, nanosphere, metal nanoparticle, quantum dot (QD), mesoporous silica nanoparticle (MSN), polymer-lipid hybrid nanoparticle (PLN), metal-organic framework (MOF), micelle, selenium nanoparticle (SeNP), magnetic nanoparticle (MNP), nanoemulsion, nanocrystal, nanodiamond (ND), dendrimer, niosome, and viral nanoparticle.

Table 1. Summary of types of NPs and their advantages and limitations.

\begin{tabular}{|c|c|c|}
\hline Nanosystems & Advantages & Limitations \\
\hline Liposomes & $\begin{array}{ll}\text { - } & \text { Biodegradability } \\
\text { - } & \text { Biocompatibility } \\
\text { - } & \text { Reduced systemic toxicity } \\
\text { - } & \text { Improved stability and circulation time of } \\
& \text { the drugs }\end{array}$ & $\begin{array}{ll}\text { - } & \text { Low drug loading } \\
\text { - } & \text { Lack of colloidal stability } \\
\text { - } & \text { Difficulties in sterilization } \\
\text { - } & \text { Some leakage of the encapsulated agent }\end{array}$ \\
\hline SLNs & 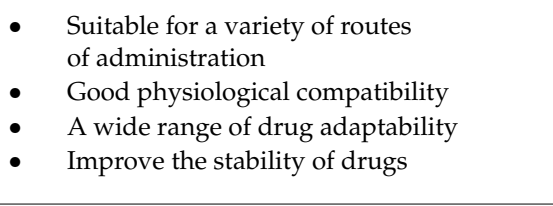 & $\begin{array}{l}\text { - } \begin{array}{l}\text { Requires organic solvent } \\
\text { during preparation }\end{array} \\
\text { Low loading capacity compared with } \\
\text { other nanocarriers } \\
\text { - } \quad \begin{array}{l}\text { Possibly containing other colloidal } \\
\text { structures and complex physical state }\end{array}\end{array}$ \\
\hline NLCs & $\begin{array}{ll}\text { - } & \text { Stability } \\
\text { - } & \text { Good biocompatibility } \\
\text { - } & \text { High drug-loading capacity } \\
\text { - } & \text { Targeting and controlled release } \\
\text { - } & \text { Improved bioavailability of drugs }\end{array}$ & - No data \\
\hline Micelles & $\begin{array}{l}\text { Suitable for water-insoluble drugs due to } \\
\text { hydrophobic core }\end{array}$ & $\begin{array}{l}\text { - Poor chemical versatility and } \\
\text { structural instability }\end{array}$ \\
\hline PMs & $\begin{array}{l}\text { - } \quad \text { Good stability } \\
\text { Allow drugs to avoid mononuclear } \\
\text { macrophages phagocytosis } \\
\text { Water-insoluble drugs can be easily } \\
\text { incorporated into PMs by the simple act } \\
\text { of mixing }\end{array}$ & $\begin{array}{l}\text { - } \quad \text { Premature drug leakage } \\
\text { - Toxicity of materials, fixed functionality } \\
\text { after synthesis } \\
\text { - } \quad \begin{array}{l}\text { Response mechanism in the human } \\
\text { body unknown }\end{array}\end{array}$ \\
\hline
\end{tabular}


Table 1. Cont.

\begin{tabular}{|c|c|c|}
\hline Nanosystems & Advantages & Limitations \\
\hline Polymeric NPs & $\begin{array}{l}\text { - } \quad \text { Targeted, controlled drug release } \\
\text { - } \quad \text { Easy surface functionalization }\end{array}$ & $\begin{array}{l}\text { - The polymer cytotoxicity } \\
\text { - } \quad \text { Difficulty in large-scale } \\
\text { industrial production } \\
\text { - The residual organic solvent in the } \\
\text { preparation process }\end{array}$ \\
\hline Dendrimers & $\begin{array}{ll}\text { - } & \text { Structural symmetry and stable nature } \\
\text { - } & \text { Has a strong EPR } \\
\text { - } & \text { Enhancement in the blood circulation time } \\
\text { - } & \text { Multiple functional groups in its surface } \\
\text { - } & \text { Customize the drug release profiles }\end{array}$ & $\begin{array}{l}\text { - Time-consuming synthesis and increased } \\
\text { - } \quad \text { Droduction costs } \\
\text { - } \quad \text { Cytotoxiculties in mass production } \\
\end{array}$ \\
\hline Niosomes & - Overcome phospholipid oxidation & - $\quad$ No data \\
\hline Nanoemulsions & $\begin{array}{l}\text { - } \quad \text { Improve drug stability } \\
\text { - } \quad \text { To avoid drug inactivation in the } \\
\text { gastrointestinal tract } \\
\text { - } \quad \text { Increase drug solubility and } \\
\text { improve bioavailability } \\
\text { - With lymphatic targeting and sustained } \\
\text { release to reduce the side effects of drugs }\end{array}$ & - $\quad$ No data \\
\hline Nanocrystals & $\begin{array}{ll}\text { - } & \text { Free of organic solvents or other } \\
\text { - } & \text { Solubilizing chemicals } \\
\text { - } & \text { High-drug loading efficiency } \\
\text { - } & \text { Steady dissolution rates } \\
\text { - } & \text { Great structural stability }\end{array}$ & $\begin{array}{l}\text { Difficulty in large-scale } \\
\text { industrial production }\end{array}$ \\
\hline Bio-NPs & $\begin{array}{ll}\text { - } & \text { Overcome various biological barriers } \\
\text { - } & \text { Lower immunogenicity and toxicity } \\
\text { - } & \text { Biocompatibility and biodegradability }\end{array}$ & - $\quad$ Limited drug loading capacity \\
\hline Exosomes & $\begin{array}{ll}\text { - } & \text { High capacity to pass through various } \\
\text { biological barriers } \\
\text { - } & \text { High stability } \\
\text { - } & \text { Less immunogenity } \\
\text { - } & \text { Natural targeting capacity }\end{array}$ & $\begin{array}{l}\text { - Specific approaches to load the desired } \\
\text { additional drugs without disturbing } \\
\text { the exosomes }\end{array}$ \\
\hline Metal NPs & $\begin{array}{ll}\text { - } & \text { Simple synthesis procedures } \\
\text { - } & \text { Modifiable (control of pore size) } \\
\text { - } & \text { Multifunctional surface functionalization }\end{array}$ & $\begin{array}{ll}- & \text { Poor biocompatibility } \\
\text { - } & \text { Low stability } \\
\text { - } & \text { Poor water solubility } \\
\end{array}$ \\
\hline $\begin{array}{c}\text { Inorganic } \\
\text { non-metallic NPs }\end{array}$ & - $\quad$ Simple synthesis procedures & - Low loading capacities \\
\hline $\begin{array}{l}\text { Hybridluhan } \\
\text { nanomedicines }\end{array}$ & $\begin{array}{ll}\text { - } & \text { Targeted delivery of drugs } \\
\text { - } & \text { Has high structural integrity } \\
\text { - } & \text { Stable storage of drugs and the controlled } \\
& \text { release of drugs } \\
\text { - } & \begin{array}{l}\text { Increased drug encapsulation efficiency } \\
\text { and biocompatibility }\end{array}\end{array}$ & - $\quad$ Potential material toxicity \\
\hline
\end{tabular}

\section{Encapsulation of Anti-Cancer Drugs with NPs}

Over the past three decades, anthracyclines and taxanes are two mainstay chemotherapeutics against cancer [78]. Anthracyclines which include DOX, epirubicin, and daunorubicin, among others, are potent DNA intercalating agents and result in DNA damage triggering apoptosis in cells by DNA interaction [79]. They are effective against cancer cells but will kill both normal and cancer cells. Among the anthracyclines, DOX is a primary therapeutic agent in combination regimens for the treatment of lymphomas, breast cancer, osteosarcoma, and other solid tumors $[2,80]$. Taxanes prevent the growth of cancer cells by destroying microtubules, so cancer cells cannot grow and divide [81]. Among the taxanes, PTX is a tetracyclic diterpene compound and used in metastatic pancreatic adenocarcinoma, breast cancer, non-small cell lung cancer (NSCLC), and ovarian cancer, while docetaxel (DTX) was licensed for the treatment of early stage and metastatic breast cancer [82]. However, the poor water solubility of taxanes limits their clinical success. DTX, a semisynthetic taxane, binds, and stabilizes microtubules by inducing G2/M arrest, thus interrupts 
cell division and inhibits tumor growth $[83,84]$. However, the clinical application of DTX has been hampered due to a number of harmful reactions, including anaphylaxis, neurotoxicity, neutropenia, peripheral neuropathy, and musculoskeletal toxicity [85]. Gemcitabine (GEM) is a fluorine-substituted deoxycytidine analogue with broad spectrum antitumor activity and its mechanism of action is based on the irreversible inhibition of DNA synthesis. However, GEM has a short half-life, and rapid body clearance, thus usually administered in higher and repeated doses, leading to many side effects [86]. It has also been demonstrated to rapidly induce drug resistance in cancer cells via many different but unclear mechanisms [87]. Carmustine (CMS) is a cell-specific nitrosourea alkylating agent, which can inhibit DNA repair and RNA synthesis in glioma cells. Due to its high lipophilicity, CMS can penetrate the blood-brain barrier (BBB) [88]. However, there are several limitations of using CMS: Short half-life, lack of selectivity to tumor cells, and short retention in the brain [89].

Drugs employed in the treatment of cancer can be loaded either by entrapment within, adsorption on, or by covalently binding to the nanoparticle [4]. As shown in Figure 3, drugs can be attached to the outer shell or the corona of NPs by covalent bonding or physical adsorption as for example by electrostatic interactions between the nanoparticle and drug, which usually exhibit low stability and become $\mathrm{pH}$ liable $[90,91]$. The non-covalent binding is simple, versatile in application, and the structure and biological activity of the drugs is exposed to minimal change. In addition, the drug releases easily and quickly in response to environmental stimuli. When the drug links to the nanocarriers by the covalent bond, leading to the enhanced solubilization of the drugs, the amplified effective concentration of the drugs is significantly amplified at the target site, and the controlled release of the drugs depending on the linkers used $[36,92,93]$. However, compared with free drugs or drug carrier complexes, covalent drug-carrier complexes have lower anticancer activities of chemotherapeutics. Drugs also could be entrapped into the core of NPs by hydrogen bonds, electrostatic, or hydrophobic interactions. Hydrophobic drugs possibly produce a hydrophobic interaction between the drug and the core of the particle, increasing its solubility [94]. The encapsulation of anticancer drugs in NPs is probably best utilized in local treatments (intratumoral injections), because, although it solubilizes the hydrophobic drugs and leaves the drug unaltered, results in toxicity and a rapid drug release may occur before reaching the target site [95].

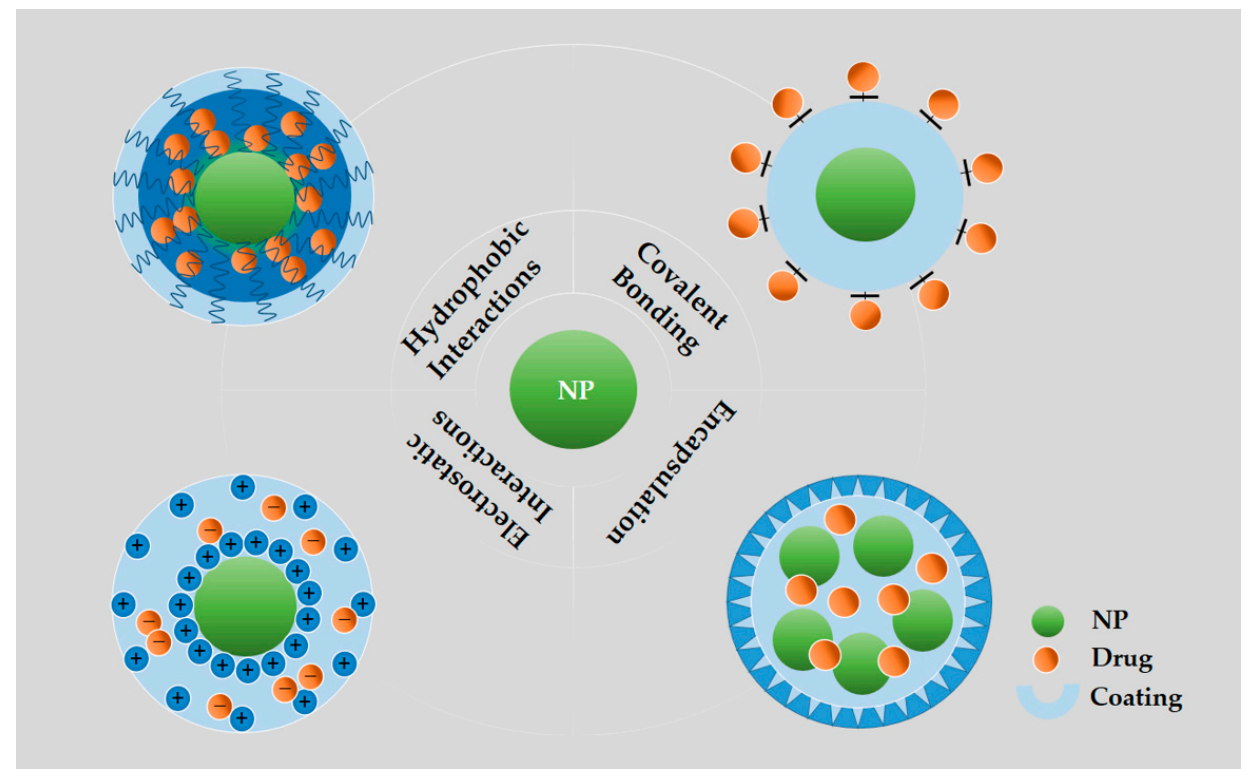

Figure 3. Illustration of various methods of loading/bonding therapeutics into NPs. Covalent bonding: Drugs directly to the surfaces of NPs through covalent bonds; Hydrophobic interactions: Partitioning hydrophobic drug molecules in an amphiphilic corona layer; Electrostatic interactions: Loading drugs onto the surfaces of NPs by electrostatic layer-by-layer assembly; Encapsulation: Loading drugs into the hollow NPs. 


\section{Application and Clinical Trials of Nanocarrier-Based Therapy in Solid Tumors}

Targeting NPs, based on the unique physical and chemical properties of the tumor microenvironment, have been widely studied for the treatment of tumors. A brief summary of the application of nano-based DDS in selected cancers is given in Table 2. Typically, the nanomedicines are designed to attack a certain molecular agent or pathway involved in the development of cancer. The selection criteria for the NPs showed in Figure 4.

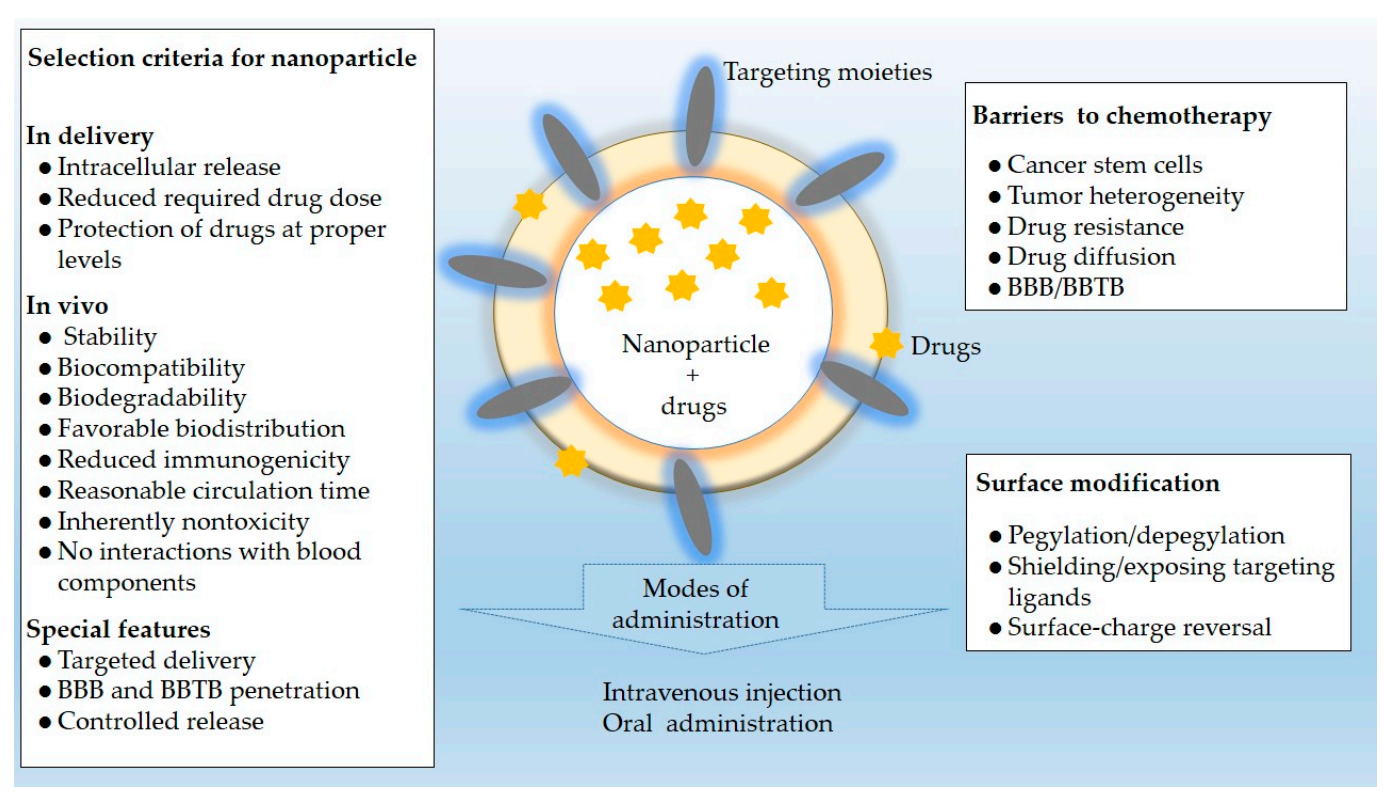

Figure 4. Selection criteria, barriers to chemotherapy, and surface modification associated with NPs for drug delivery in selected solid tumors mentioned in this review. 
Table 2. A brief summary of the application of nano-based DDS in selected cancers.

\begin{tabular}{|c|c|c|c|c|c|c|}
\hline $\begin{array}{l}\text { Studying } \\
\text { Group [Ref.] }\end{array}$ & $\begin{array}{l}\text { NPs } \\
\text { Description }\end{array}$ & $\begin{array}{l}\text { Targeting } \\
\text { Mechanism }\end{array}$ & Target & Drug(s) & Cancer Model & Results of Findings \\
\hline $\begin{array}{l}\text { Kim et al. } \\
\text { (2016) [96] }\end{array}$ & Exosome & $\begin{array}{l}\text { Specific } \\
\text { endocytosis and/or } \\
\text { fusion with plasma } \\
\text { membranes }\end{array}$ & No data & PTX & $\begin{array}{l}\text { 3LL-M27 cells; } \text { MDCK }_{\mathrm{WT}} \text { and } \\
\text { resistant MDCK } \\
\text { pulmon } 1 \text { cancer cells; } \\
\text { lung carcinoma }(\mathrm{LLC}) \\
\text { mouse model }\end{array}$ & $\begin{array}{l}\text { The incorporation of PTX into exosomes } \\
\text { significantly increased drug accumulation } \\
\text { levels in both sensitive and resistant cancer } \\
\text { cells; a significant }(p<0.05) \text { inhibition of } \\
\text { metastases growth by exoPTX treatment } \\
\text { was demonstrated }\end{array}$ \\
\hline $\begin{array}{l}\text { Iannazzo et al. } \\
\text { (2017) [97] }\end{array}$ & QDs & $\begin{array}{l}\text { Active } \\
\text { targeting }\end{array}$ & Biotin receptors & DOX & A549 cells & $\begin{array}{l}\text { Improved delivery of conventional } \\
\text { chemotherapeutics by using QDs } \\
\text { as nanocarrier }\end{array}$ \\
\hline $\begin{array}{l}\text { Zhao et al. } \\
\text { (2017) [98] }\end{array}$ & Micelles & $\begin{array}{l}\text { Passive } \\
\text { targeting }\end{array}$ & EPR & $\begin{array}{l}\text { PTX and } \\
\text { DOX }\end{array}$ & A549 cells & $\begin{array}{l}\text { A fixed and high drug loading content of } \\
24.2 \% \text { (PTX 14.8\% and DOX 9.4\%) with a } \\
\text { precise ratio of PTX and DOX to realize the } \\
\text { synchronized and controlled release }\end{array}$ \\
\hline $\begin{array}{l}\text { Xie et al. } \\
\text { (2019) [99] }\end{array}$ & PMs & $\begin{array}{l}\text { Not } \\
\text { mentioned }\end{array}$ & No data & $\begin{array}{l}\text { PTX and } \\
\text { ligustrazine }\end{array}$ & $\begin{array}{l}\text { A549 cell lines; } \\
\text { xenograft tumor mice model }\end{array}$ & $\begin{array}{l}\text { Strong inhibition on tumor metastasis; } \\
\text { enhance the accumulation of drugs at tumor } \\
\text { sites; tumor volume ratios were } 26.47 \% \pm \\
8.23 \text { for blank control, } 21.43 \% \pm 9.45 \text { for free } \\
\text { PTX, } 14.65 \% \pm 8.13 \text { for dequalinium (DQA) } \\
\text { modified PTX plus ligustrazine micelles, } \\
\text { respectively }\end{array}$ \\
\hline $\begin{array}{l}\text { Zou et al. } \\
\text { (2019) [100] }\end{array}$ & SeNPs & $\begin{array}{l}\text { Specific } \\
\text { endocytosis }\end{array}$ & CD44 receptor & PTX & $\begin{array}{l}\text { A549 cell lines; } \\
\text { A549 tumor-bearing mice }\end{array}$ & $\begin{array}{l}\text { Greater uptake of PTX in A549 cells; } \\
\text { negligible toxicity; PTX and HA-Se@PTX at } \\
4 \mu \mathrm{g} / \mathrm{mL} \text { PTX dose dramatically inhibited } \\
\text { the proliferation of A549 cells and the cell } \\
\text { viability rates were } 64.8 \text {, and } \\
34.5 \% \text {, respectively }\end{array}$ \\
\hline $\begin{array}{l}\text { Wu et al. } \\
\text { (2019) [101] }\end{array}$ & Dendrimers & $\begin{array}{l}\text { Coating with } \\
\text { targeting cancer cell } \\
\text { membrane proteins }\end{array}$ & No data & DOX and icotinib & $\begin{array}{l}\text { H1975, HCC } 827 \text {, and B16 cell lines; } \\
\text { H1975 tumor-bearing mice }\end{array}$ & $\begin{array}{l}\text { High stability; superior targeting ability; } \\
\text { minimal side effects; at the physiological pH } \\
7.4 \text {, only } 30.1 \% \text { of the DOX and } 27.3 \% \text { of } \\
\text { icotinib were released from the dendrimers } \\
\text { within } 48 \text { h; the H1975 cell } \\
\text { membrane-coated dendrimers resulted in } \\
87.56 \% \text { tumor inhibition, with the tumor } \\
\text { weight } 8.75 \text {-fold less compared to that of the } \\
\text { PBS control group }\end{array}$ \\
\hline
\end{tabular}


Table 2. Cont.

\begin{tabular}{|c|c|c|c|c|c|c|}
\hline $\begin{array}{l}\text { Studying } \\
\text { Group [Ref.] }\end{array}$ & $\begin{array}{l}\text { NPs } \\
\text { Description }\end{array}$ & $\begin{array}{l}\text { Targeting } \\
\text { Mechanism }\end{array}$ & Target & Drug(s) & Cancer Model & Results of Findings \\
\hline $\begin{array}{l}\text { Huang et al. } \\
\text { (2019) [102] }\end{array}$ & PMs & $\begin{array}{l}\text { Active } \\
\text { targeting }\end{array}$ & $\begin{array}{l}\mathrm{CD} 133 \text { and } \mathrm{CD} 44 \\
\text { receptor }\end{array}$ & Gefitinib & $\begin{array}{l}\text { H446 and A549 cell lines; xenograft } \\
\text { tumor mice model }\end{array}$ & $\begin{array}{l}\text { The drug loading of the nanomicelles in } \\
\text { each group was } 7-9 \% \text { and the encapsulation } \\
\text { efficiency was } \sim 80 \% \text {; exhibited greater } \\
\text { therapeutic efficacy against lung } \\
\text { cancer-initiating cells than single-target }\end{array}$ \\
\hline $\begin{array}{l}\text { Zhang et al. } \\
\text { (2019) [103] }\end{array}$ & Polymeric NPs & $\begin{array}{l}\text { Specific } \\
\text { endocytosis }\end{array}$ & $\begin{array}{l}\text { Epidermal growth } \\
\text { factor receptor } \\
\text { (EGFR) }\end{array}$ & $\begin{array}{l}\text { Homoharringtonine } \\
\text { (HHT) }\end{array}$ & $\begin{array}{l}\text { BEAS-2B, A549, and NCI-H226 cell } \\
\text { lines; A549 tumor bearing mice }\end{array}$ & $\begin{array}{l}\text { Better therapeutic efficacy and fewer side } \\
\text { effects; targeted recognition and stimuli } \\
\text { response; the IC } 50 \text { of the nanomedicine is } \\
5.1 \mathrm{nM} \text {, while the IC50 of free HHT reaches } \\
\text { up to } 23.2 \mathrm{nM} \text {, a } 4.5 \text {-fold increase }\end{array}$ \\
\hline $\begin{array}{l}\text { He et al. } \\
(2020) \text { [104] }\end{array}$ & PMs & $\begin{array}{l}\text { Not } \\
\text { mentioned }\end{array}$ & No data & PTX & $\begin{array}{l}\text { A549 cells; A549 tumor bearing } \\
\text { mice }\end{array}$ & $\begin{array}{l}\text { Enhanced the retention of drugs in the } \\
\text { tumor; sustained drug release property; the } \\
\text { IC } 50 \text { values of the PTX micelles at } 24 \mathrm{~h} \text { with } \\
\text { no ambroxol (Ax) or combined with } 100 \mu \mathrm{M} \\
\text { Ax were } 87.09 \pm 4.12 \mathrm{ng} / \mathrm{mL} \text { and } \\
1.14 \pm 0.08 \mathrm{ng} / \mathrm{mL} \text {, respectively }\end{array}$ \\
\hline $\begin{array}{l}\text { Liang et al. } \\
(2020) \text { [105] }\end{array}$ & NLCs & $\begin{array}{l}\text { Specific } \\
\text { endocytosis }\end{array}$ & Glucose & PTX and GEM & $\begin{array}{l}\text { LTEP-a-2, L929, and A549 cell lines; } \\
\text { A549 tumor bearing mice }\end{array}$ & $\begin{array}{l}\text { Targeted intracellular sequential drug } \\
\text { release; the tumor volume in } \\
\text { dual-drugs-loaded NLCs group was } 2.6 \text {-fold } \\
\text { smaller than those treated with the free } \\
\text { drug combination }\end{array}$ \\
\hline $\begin{array}{l}\text { Zhang et al. } \\
\text { (2015) [106] }\end{array}$ & Nanocrystals & $\begin{array}{l}\text { Not } \\
\text { mentioned }\end{array}$ & No data & PTX & $\begin{array}{l}\text { MDA-MB-231/Luc cells; } \\
\text { MDA-MB-231/Luc tumor bearing } \\
\text { mice }\end{array}$ & $\begin{array}{l}\text { PEGylated PTX nanocrystals significantly } \\
\text { enhanced the antitumor effect in treating in } \\
\text { situ tumor or metastatic tumor bearing mice } \\
\text { after intravenous administration }\end{array}$ \\
\hline $\begin{array}{l}\text { Guven et al. } \\
\text { (2017) [107] }\end{array}$ & CNTs & $\begin{array}{l}\text { Passive } \\
\text { targeting }\end{array}$ & EPR & Cisplatin & $\begin{array}{l}\text { MCF- } 7 \text { and MDA-MB-231 tumor } \\
\text { bearing mice }\end{array}$ & $\begin{array}{l}\text { A prolonged circulation time compared to } \\
\text { free cisplatin which EPR effects resulting in } \\
\text { significantly more cisplatin accumulation } \\
\text { in tumors }\end{array}$ \\
\hline $\begin{array}{l}\text { Li et al. } \\
\text { (2017) [108] }\end{array}$ & PLNs & $\begin{array}{l}\text { Active } \\
\text { targeting }\end{array}$ & $\begin{array}{l}\text { Human epidermal } \\
\text { growth factor } \\
\text { receptor-2 (HER-2) }\end{array}$ & Salinomycin & $\begin{array}{l}\text { BT-474 ALDH+ and ALDH- cell; } \\
\text { MDA-MB-361 } \\
\text { ALDH+ and ALDH- cells; BT- } 474 \\
\text { tumor bearing mice }\end{array}$ & $\begin{array}{l}\text { Achieved the best therapeutic efficacy, } \\
\text { resulting in a } 79 \% \text { decrease in tumor } \\
\text { volume, whereas salinomycin obtained only } \\
\text { moderate therapeutic efficacy } \\
\text { ( } 43 \% \text { decrease) }\end{array}$ \\
\hline
\end{tabular}


Table 2. Cont

\begin{tabular}{|c|c|c|c|c|c|c|}
\hline $\begin{array}{l}\text { Studying } \\
\text { Group [Ref.] }\end{array}$ & $\begin{array}{l}\text { NPs } \\
\text { Description }\end{array}$ & $\begin{array}{l}\text { Targeting } \\
\text { Mechanism }\end{array}$ & Target & Drug(s) & Cancer Model & Results of Findings \\
\hline $\begin{array}{l}\text { Le et al. } \\
\text { (2017) [109] }\end{array}$ & Viral NPs & $\begin{array}{l}\text { Not } \\
\text { mentioned }\end{array}$ & No data & DOX & $\begin{array}{l}\text { MDA-MB- } 231 \text { cells; MDA-MB- } 231 \\
\text { tumor bearing mice }\end{array}$ & $\begin{array}{l}\text { DOX-loaded viral NPs demonstrated } \\
\text { efficacy in MDA-MB- } 231 \text { cell although at } \\
\text { lower efficacy than free DOX }\end{array}$ \\
\hline $\begin{array}{l}\text { Jiang et al. } \\
\text { (2018) [110] }\end{array}$ & SiNPs & $\begin{array}{l}\text { Not } \\
\text { mentioned }\end{array}$ & No data & DOX & $\begin{array}{l}\text { EMT- } 6 \text { and MCF - } 7 \text { cell lines; } \\
\text { EMT- } 6 \text { tumor bearing mice }\end{array}$ & $\begin{array}{l}\text { The tumor size and weight of DOX loaded } \\
\text { SiNPs group was 2-fold and 1.7-fold smaller } \\
\text { than that of free DOX group, and 4-fold and } \\
\text { 2-fold smaller than that of PBS group }\end{array}$ \\
\hline $\begin{array}{l}\text { Zheng et al. } \\
\text { (2019) [111] }\end{array}$ & SLNs & $\begin{array}{l}\mathrm{pH} \\
\text { sensitivity }\end{array}$ & No data & DOX & $\begin{array}{l}\text { MCF cells lines; } \\
\text { MCF/ADR DOX-resistant cells; } \\
\text { MCF/ADR tumor bearing mice }\end{array}$ & $\begin{array}{l}\text { RGD-DOX-SLNs showed } 5.58 \text { fold higher } \\
\text { area under the plasma concentration-time } \\
\text { curve (AUC) compared with DOX solution; } \\
\text { terminal half life }\left(\mathrm{T}_{1 / 2}\right) \text { and peak } \\
\text { concentration }\left(\mathrm{C}_{\max }\right) \text { of RGD-DOXSLNs } \\
\text { was } 10.85 \mathrm{~h} \text { and } 39.12 \pm 2.71 \mathrm{~L} / \mathrm{kg} / \mathrm{h}\end{array}$ \\
\hline $\begin{array}{l}\text { Fang et al. } \\
\text { (2019) [112] }\end{array}$ & Polymeric NPs & $\begin{array}{l}\text { Active } \\
\text { targeting }\end{array}$ & CD44 receptor & DTX & $\begin{array}{l}\text { 4T1-Luc cells lines; } 4 \mathrm{~T} 1 \text {-Luc tumor } \\
\text { bearing mice }\end{array}$ & $\begin{array}{l}\text { Drug loading efficiency }(76.3-80.4 \%) \text {; steady } \\
\text { in a nonreducing environment while was } \\
\text { destabilized under } 10 \mathrm{mM} \text { glutathione } \\
\text { releasing } ~ 90 \% \text { of the DTX within } 24 \mathrm{~h} \text {; } \\
\text { selective cellular uptake }\end{array}$ \\
\hline $\begin{array}{l}\text { Li et al. } \\
\text { (2019) [113] }\end{array}$ & Liposome & $\begin{array}{l}\text { Passive } \\
\text { targeting }\end{array}$ & EPR & $\begin{array}{l}\text { Poria cocos extract } \\
\text { and DOX }\end{array}$ & $\begin{array}{l}\text { MCF cells lines; } \\
\text { MCF/ADR DOX-resistant cells; } \\
\text { MCF/ADR tumor bearing mice }\end{array}$ & $\begin{array}{l}\text { Higher safety; sensitized DOX to kill cells in } \\
\text { drug-resistant tumors; the release rates of } \\
\text { poria cocos extract from the liposome were > } \\
70 \% \text { within } 6-8 \mathrm{~h} \text {, while DOX was released } \\
\text { completely after } 12 \mathrm{~h}\end{array}$ \\
\hline $\begin{array}{l}\text { Lei et al. } \\
\text { (2019) [114] }\end{array}$ & MOFs & $\begin{array}{l}\text { Passive } \\
\text { targeting }\end{array}$ & EPR & DOX & $\begin{array}{l}\text { 4T1, MDA-MB-231, MCF-7, and } \\
\text { ZR-75-30 cell lines; } 4 \mathrm{~T} 1 \text { tumor } \\
\text { bearing mice }\end{array}$ & $\begin{array}{l}\text { Good safety profile; highly effective } \\
\text { antitumor ability }\end{array}$ \\
\hline $\begin{array}{l}\text { Dancy et al. } \\
(2020) \text { [115] }\end{array}$ & Polymeric NPs & $\begin{array}{l}\text { Active } \\
\text { targeting }\end{array}$ & $\begin{array}{l}\text { Fibroblast growth } \\
\text { factor-inducible } 14 \\
\text { (Fn14) receptor }\end{array}$ & PTX & $\begin{array}{l}\text { 231-Luc cell lines; } \\
\text { 231-Luc tumor-bearing mice; } \\
\text { 231-Br-Luc tumor-bearing mice }\end{array}$ & $\begin{array}{l}\text { Tumor cell-specific uptake; long blood } \\
\text { circulation time; excellent tumor tissue } \\
\text { penetration; the average tumor doubling } \\
\text { time in the NPs treated mice was } 32 \text { days } \\
\text { compared to } 17 \text { and } 20 \text { days for saline- or } \\
\text { Abraxane-treated mice, respectively }\end{array}$ \\
\hline $\begin{array}{l}\text { Han et al. } \\
\text { (2020) [116] }\end{array}$ & Liposomes & $\begin{array}{l}\text { Specific } \\
\text { endocytosis }\end{array}$ & ERs & PTX & $\begin{array}{l}\text { MCF-7 cell lines; } \\
\text { MCF-7 tumor bearing mice }\end{array}$ & $\begin{array}{l}\text { Encapsulation efficiency of } 88.07 \pm 1.25 \% \text {; } \\
\text { prolonged half-life of the drug; the } \\
\text { elimination half-lives of PTX and PTX } \\
\text { liposomes were } 1.79 \text { and } 20.98 \mathrm{~h} \text {, respectively }\end{array}$ \\
\hline
\end{tabular}


Table 2. Cont.

\begin{tabular}{|c|c|c|c|c|c|c|}
\hline $\begin{array}{l}\text { Studying } \\
\text { Group [Ref.] }\end{array}$ & $\begin{array}{l}\text { NPs } \\
\text { Description }\end{array}$ & $\begin{array}{l}\text { Targeting } \\
\text { Mechanism }\end{array}$ & Target & Drug(s) & Cancer Model & Results of Findings \\
\hline $\begin{array}{l}\text { Zafar et al. } \\
(2020) \text { [117] }\end{array}$ & LNCs & $\begin{array}{l}\text { Passive } \\
\text { targeting }\end{array}$ & EPR & DTX and THQ & $\begin{array}{l}\text { MCF-7 and MDA-MB- } 231 \text { cell lines; } \\
\text { Ehrlich ascites carcinoma bearing } \\
\text { mice }\end{array}$ & $\begin{array}{l}\text { Encapsulation efficiency of DTX and THQ } \\
\text { were found to be } 86.79 \pm 3.79 \% \text { and } 95.17 \pm \\
1.61 \% \text {, respectively; controlled drug release; } \\
\text { re-sensitized cancer cells to DTX; a } \\
2.85 \text {-folds decrease in tumor volume was } \\
\text { observed with LNCs treated group } \\
\text { compared to control group }\end{array}$ \\
\hline $\begin{array}{l}\text { Xu et al. } \\
(2020)[118]\end{array}$ & PMs & $\begin{array}{l}\text { Active } \\
\text { targeting }\end{array}$ & Sialic acid residues & DOX & $\begin{array}{l}\text { MCF-7/ADR cell lines; } \\
\text { MCF-7/ADR tumor bearing mice }\end{array}$ & $\begin{array}{l}\text { MDR reversal; good stability in neutral } \\
\text { environment; } \sim 50 \% \text { MCF-7/ADR cells were } \\
\text { killed with DOX micelles treated compared } \\
\text { to } \sim 15 \% \text { cells death induced by free DOX }\end{array}$ \\
\hline $\begin{array}{l}\text { Guo et al. } \\
\text { (2020) [91] }\end{array}$ & RNA NPs & $\begin{array}{l}\text { Active } \\
\text { targeting }\end{array}$ & EGFR & PTX & $\begin{array}{l}\text { MDA-MB-231 cell lines; } \\
\text { MDA-MB-231 tumor bearing mice }\end{array}$ & $\begin{array}{l}\text { Undetectable toxicity or immune } \\
\text { stimulation; the in vitro cell apoptosis assay } \\
\text { revealed that } 45.1 \% \text { of the cells underwent } \\
\text { apoptosis after } 24 \mathrm{~h} \text { treatment with RNA } \\
\text { NPs, in comparison to free PTX }(24.6 \%)\end{array}$ \\
\hline $\begin{array}{l}\text { Teijeiro-Valiño } \\
\text { et al. (2018) } \\
\text { [119] }\end{array}$ & Polymeric NPs & $\begin{array}{l}\text { Active } \\
\text { targeting }\end{array}$ & CD44 receptor & DTX & $\begin{array}{l}\text { A549 lung cancer cells; orthotopic } \\
\text { lung cancer model; PC patient } \\
\text { derived xenograft model }\end{array}$ & $\begin{array}{l}\text { Dual targeting properties (to the tumor and } \\
\text { to the lymphatics); a dramatic accumulation } \\
\text { of DTX in the tumor ( } 37 \text {-fold the one } \\
\text { achieved with Taxotere }{ }^{\circledR} \text { ) }\end{array}$ \\
\hline $\begin{array}{l}\text { Lin et al. } \\
\text { (2019) [120] }\end{array}$ & Liposome & $\begin{array}{l}\text { Specific } \\
\text { endocytosis }\end{array}$ & EGFR & $\begin{array}{l}\text { GEM and } \\
\text { HIF1 } \alpha \text {-siRNA }\end{array}$ & $\begin{array}{l}\text { PANC-1 cell lines; PANC-1 tumor } \\
\text { bearing mice }\end{array}$ & $\begin{array}{l}\text { Increased targeting specificity of liposome } \\
\text { carrier; increased the total amount of } \\
\text { apoptosis cells; GE-GML/siRNA showed } \\
\text { 4-fold reduction in tumor compared to } \\
\text { control group }\end{array}$ \\
\hline $\begin{array}{l}\text { Madamsetty et } \\
\text { al. (2019) [121] }\end{array}$ & NDs & $\begin{array}{l}\text { Passive } \\
\text { targeting }\end{array}$ & EPR & DOX & $\begin{array}{l}\text { BxPC3, } 6741 \text { and PANC-1 cell lines; } \\
\text { orthotopic PDAC xenograft model }\end{array}$ & $\begin{array}{l}\text { A considerable improvement over free drug; } \\
\text { no abnormalities of major organs; NDs } \\
\text { alone showed no cytotoxicity at doses up to } \\
25 \mu \mathrm{g} / \mathrm{mL} \text {, irrespective of whether the cells } \\
\text { were grown in the absence or } \\
\text { presence of FBS }\end{array}$ \\
\hline
\end{tabular}


Table 2. Cont.

\begin{tabular}{|c|c|c|c|c|c|c|}
\hline $\begin{array}{l}\text { Studying } \\
\text { Group [Ref.] }\end{array}$ & $\begin{array}{l}\text { NPs } \\
\text { Description }\end{array}$ & $\begin{array}{l}\text { Targeting } \\
\text { Mechanism }\end{array}$ & Target & Drug(s) & Cancer Model & Results of Findings \\
\hline $\begin{array}{l}\text { Massey et al. } \\
\text { (2019) [122] }\end{array}$ & Polymeric NPs & $\begin{array}{l}\text { Not } \\
\text { mentioned }\end{array}$ & No data & PTX & $\begin{array}{l}\text { AsPC1, PANC-1, MIA PaCa-2, and } \\
\text { HPAF-II cell lines }\end{array}$ & $\begin{array}{l}\text { NPs administration }(10 \mathrm{mg} / \mathrm{kg}) \text { significantly } \mathrm{y} \\
(\mathrm{P}<<0.05) \text { inhibited tumor growth, even in } \\
\text { pre-exposed mice as determined by } \\
\text { significant }(\mathrm{P}<<0.05) \text { inhibition of } \\
\text { bioluminescence counts ideal properties for } \\
\text { nano-scale drug delivery; }\end{array}$ \\
\hline $\begin{array}{l}\text { Madamsetty et } \\
\text { al. (2019) [123] }\end{array}$ & NDs & $\begin{array}{l}\text { Passive } \\
\text { targeting }\end{array}$ & EPR & $\begin{array}{l}\text { Irinotecan and } \\
\text { curcumin }\end{array}$ & $\begin{array}{l}\text { AsPC-1 and PANC- } 1 \text { cells; } \\
\text { orthotopic PDAC xenograft model }\end{array}$ & $\begin{array}{l}\text { Exerted immunomodulatory effects; } \\
\text { dual payload }\end{array}$ \\
\hline $\begin{array}{l}\text { Sun et al. } \\
(2020)[124]\end{array}$ & PMs & $\begin{array}{l}\text { Passive } \\
\text { targeting }\end{array}$ & EPR & NLG919 and PTX & $\begin{array}{l}\text { PANC02 and H7 cell lines; } \\
\text { PANC02 tumor bearing mice; } 4 \mathrm{~T} 1 \\
\text { BC model }\end{array}$ & $\begin{array}{l}\text { Improved tumor inhibition effect; more } \\
\text { immunoactive tumor microenvironment; } \\
\text { micelles showed a more favorable release } \\
\text { kinetics of PTX, and only } 35 \% \text { of PTX was } \\
\text { slowly released within } 72 \mathrm{~h}\end{array}$ \\
\hline $\begin{array}{l}\text { Etman et al. } \\
(2020)[125]\end{array}$ & Polymeric NPs & $\begin{array}{l}\text { Specific } \\
\text { endocytosis }\end{array}$ & $\begin{array}{l}\text { Lactoferrin (Lf) and } \\
\text { CD44 receptors }\end{array}$ & Quinacrine (QC) & $\begin{array}{l}\text { PANC-1 cell lines; orthotopic PC } \\
\text { model }\end{array}$ & $\begin{array}{l}\mathrm{pH} \text { triggered release; the loading efficiency } \\
\text { of the dual coated formulation was } 19.5 \pm \\
1.9 \% \text { compared to } 23.6 \pm 2.4 \% \text { for } \\
\text { uncoated formulation. }\end{array}$ \\
\hline $\begin{array}{l}\text { Elechalawar et } \\
\text { al. (2020) [126] }\end{array}$ & $\mathrm{Au}$ NPs & $\begin{array}{l}\text { Active } \\
\text { targeting }\end{array}$ & EGFR & GEM & $\begin{array}{l}\text { PANC-1, AsPC-1, CAF-19, and } \\
\text { HPDE cell lines }\end{array}$ & $\begin{array}{l}\text { Enhanced cellular uptake and cytotoxicity to } \\
\text { pancreatic cancer cells (PCCs) }\end{array}$ \\
\hline $\begin{array}{l}\text { Han et al. } \\
\text { (2020) [127] }\end{array}$ & MNPs & $\begin{array}{l}\text { Active } \\
\text { targeting }\end{array}$ & No data & GEM & $\begin{array}{l}\text { PANC-1 and HUVEC cell lines; } \\
\text { PANC- } 1 \text { tumor bearing mice }\end{array}$ & $\begin{array}{l}\text { Targeted delivery and effective } \\
\text { accumulation; the GEM-loaded MNPs } \\
\text { exhibited higher cytotoxicity at } \mathrm{pH} 6.5 \text { than } \\
\text { that at } \mathrm{pH} \text { 7.4, which might be attributed to } \\
\text { pH-dependent enhanced cellular uptake }\end{array}$ \\
\hline $\begin{array}{l}\text { Zhai et al. } \\
\text { (2018) [128] }\end{array}$ & $\mathrm{APO}$ & $\begin{array}{l}\text { Specific } \\
\text { endocytosis }\end{array}$ & $\begin{array}{l}\text { Transferrin receptor } \\
1 \text { (TfR1) and } \\
\text { heparan sulfate } \\
\text { proteoglycan }\end{array}$ & $\begin{array}{l}\text { Vincristine sulfate } \\
\text { (VCR) }\end{array}$ & $\begin{array}{l}\text { bEnd.3, HUVEC, and U87MG cell } \\
\text { lines; U87MG tumor bearing mice }\end{array}$ & $\begin{array}{l}\text { Higher glioma localization; the VCR } \\
\text { encapsulation efficiency was approximately } \\
39.8 \pm 0.9 \% \text {; treatment with this NPs } \\
\text { significantly prolonged the median surviva } \\
\text { time ( } 35 \text { days), which was } 1.8 \text { and } 1.6 \text {-fold } \\
\text { higher than that of physiological saline and } \\
\text { free VCR, respectively }\end{array}$ \\
\hline $\begin{array}{l}\text { Guo et al. } \\
(2018)[129]\end{array}$ & PMs & $\begin{array}{l}\text { Specific } \\
\text { endocytosis }\end{array}$ & IL-13R & CMS & $\begin{array}{l}\text { BT325 cell lines; Luc-BT325 tumor } \\
\text { bearing mice }\end{array}$ & $\begin{array}{l}\text { BBB penetration; targeting glioma cells; the } \\
\text { apoptosis rate of BT } 325 \text { cells induced by the } \\
\text { PMs nearly } 80 \%\end{array}$ \\
\hline
\end{tabular}


Table 2. Cont.

\begin{tabular}{|c|c|c|c|c|c|c|}
\hline $\begin{array}{l}\text { Studying } \\
\text { Group [Ref.] }\end{array}$ & $\begin{array}{l}\text { NPs } \\
\text { Description }\end{array}$ & $\begin{array}{l}\text { Targeting } \\
\text { Mechanism }\end{array}$ & Target & Drug(s) & Cancer Model & Results of Findings \\
\hline $\begin{array}{l}\text { Zou et al. } \\
\text { (2018) [130] }\end{array}$ & Polymeric NPs & $\begin{array}{l}\text { Specific } \\
\text { endocytosis }\end{array}$ & $\begin{array}{l}\text { Lipoprotein } \\
\text { receptor related } \\
\text { protein receptor }\end{array}$ & $\begin{array}{l}\text { DOX and lexiscan } \\
\text { (Lex) }\end{array}$ & U87MG tumor bearing mice & $\begin{array}{l}\text { Improved blood circulation time; BBB } \\
\text { penetration; the biodistribution of } \\
\text { nanomedicines demonstrated that } \\
\text { orthotopic brain tumor accumulation was } \\
21.9 \text { fold higher than that of free } \\
\text { DOX controls }\end{array}$ \\
\hline $\begin{array}{l}\text { Meng et al. } \\
\text { (2019) [131] }\end{array}$ & PMs & $\begin{array}{l}\text { Not } \\
\text { mentioned }\end{array}$ & No data & DOX & $\begin{array}{l}\text { HBMEC and C6 cell lines; } \\
\text { GBM-bearing mice model }\end{array}$ & $\begin{array}{l}\text { The drug encapsulation efficiency and } \\
\text { loading capacity in DOX BO-PMs were } \\
(95.69 \pm 0.49) \% \text { and }(14.62 \pm 0.39) \% \text {, } \\
\text { respectively; enhanced the transport } \\
\text { efficiency of DOX across the BBB; exhibited } \\
\text { a quick accumulation in the brain tissues }\end{array}$ \\
\hline $\begin{array}{l}\text { Wang et al. } \\
\text { (2019) [132] }\end{array}$ & Nanoemulsion & $\begin{array}{l}\text { Active } \\
\text { targeting }\end{array}$ & CD44 and nucleolin & $\begin{array}{l}\text { Shikonin (SKN) and } \\
\text { DTX }\end{array}$ & $\begin{array}{l}\text { U87 cell lines; orthotopic } \\
\text { luciferase-transfected-U87 bearing } \\
\text { nude mice }\end{array}$ & $\begin{array}{l}\text { BBB penetration; overwhelming inhibition } \\
\text { of the orthotopic luciferase-transfected-U87 } \\
\text { glioma-bearing nude mice; after incubating } \\
\text { cells for } 8 \mathrm{~h} \text {, the nanoemulsion induced } \\
\text { apoptosis in } 71.3 \pm 4.2 \% \text { of U87 cells }\end{array}$ \\
\hline $\begin{array}{l}\text { Younis et al. } \\
\text { (2019) [133] }\end{array}$ & Polymeric NPs & $\begin{array}{l}\text { Not } \\
\text { mentioned }\end{array}$ & No data & Iguratimod (IGU) & $\begin{array}{l}\text { U87, U118, and U251 cell lines; } \\
\text { xenograft tumor mice model }\end{array}$ & $\begin{array}{l}\text { Without any visible organ toxicity; } \\
\text { significant inhibition of tumor growth; } \\
\text { cross BBB }\end{array}$ \\
\hline $\begin{array}{l}\text { Caban- } \\
\text { Toktas et al. } \\
\text { (2020) [134] }\end{array}$ & Polymeric NPs & $\begin{array}{l}\text { Not } \\
\text { mentioned }\end{array}$ & No data & $\begin{array}{l}\text { R-flurbiprofen and } \\
\text { PTX }\end{array}$ & $\begin{array}{l}\text { RG2 cell lines; Rat RG2 glioma } \\
\text { tumor model }\end{array}$ & $\begin{array}{l}\text { Reduced inflammation in the peri-tumoral } \\
\text { area; enhanced anti-tumoral activity } \\
\text { against glioma }\end{array}$ \\
\hline $\begin{array}{l}\text { Zhang et al. } \\
\text { (2018) [135] }\end{array}$ & Polymeric NPs & $\begin{array}{l}\text { Specific } \\
\text { endocytosis }\end{array}$ & $\begin{array}{l}\text { Asialoglycoprotein } \\
\text { receptors (ASGP-R) }\end{array}$ & Triptolide (TP) & $\begin{array}{l}\text { SMMC7721 and A549 cells; HCC } \\
\text { xenograft mouse model; orthotopic } \\
\text { HCC mice model }\end{array}$ & $\begin{array}{l}\text { Sustained release; targeted delivery; high } \\
\text { liver tumor accumulation in vivo }\end{array}$ \\
\hline $\begin{array}{l}\text { Yao et al. } \\
\text { (2019) [136] }\end{array}$ & Liposome & $\begin{array}{l}\text { Not } \\
\text { mentioned }\end{array}$ & No data & $\begin{array}{l}\text { Sorafenib (Sf) and } \\
\text { VEGF-siRNA }\end{array}$ & $\begin{array}{l}\text { HepG2 cells; H22 tumor-bearing } \\
\text { mice }\end{array}$ & Improved anti-tumor efficiency \\
\hline $\begin{array}{l}\text { Han et al. } \\
\text { (2019) [137] }\end{array}$ & Polymeric NPs & $\begin{array}{l}\text { Not } \\
\text { mentioned }\end{array}$ & No data & $\begin{array}{l}\text { Polymeric SN38 } \\
\text { prodrugs (pSN38) } \\
\text { and apatinib (Apa) }\end{array}$ & $\begin{array}{l}\text { Huh-7, LM3, and HepG2 cell lines; } \\
\text { HCC xenograft mouse model }\end{array}$ & $\begin{array}{l}\text { Reduced drug resistance; the sequential } \\
\text { release of both encapsulated drugs }\end{array}$ \\
\hline $\begin{array}{l}\text { Zhang et al. } \\
\text { (2019) [138] }\end{array}$ & MSNs & Specific endocytosis & CD44 receptor & $\begin{array}{l}\text { DOX and berberine } \\
\text { (BER) }\end{array}$ & $\begin{array}{l}\text { HepG2, H22, HL-7702, HCC cells, } \\
\text { and NIH-3T3 cell lines; H22 } \\
\text { tumor-bearing mice }\end{array}$ & $\begin{array}{l}\text { Efficient tumor-inhibiting effects; decreased } \\
\text { regrowth activity; the apoptotic rates of } \\
\text { DOX+BER and DOX+BER loaded MSNs } \\
\text { were } 34.93 \text { and } 48.10 \% \text {, respectively }\end{array}$ \\
\hline
\end{tabular}


Table 2. Cont.

\begin{tabular}{|c|c|c|c|c|c|c|}
\hline $\begin{array}{l}\text { Studying } \\
\text { Group [Ref.] }\end{array}$ & $\begin{array}{l}\text { NPs } \\
\text { Description }\end{array}$ & $\begin{array}{l}\text { Targeting } \\
\text { Mechanism }\end{array}$ & Target & Drug(s) & Cancer Model & Results of Findings \\
\hline $\begin{array}{l}\text { Xu et al. } \\
\text { (2019) [139] }\end{array}$ & Oxide NPs & Specific endocytosis & CD44 receptor & $\begin{array}{l}\mathrm{DOX} \text { and } \mathrm{Cu} \\
(\mathrm{DDC})_{2}\end{array}$ & $\begin{array}{l}\text { MCF-7 and HepG2 cell lines; } \\
\text { mouse models of ectopic } \\
\text { hepatocellular carcinoma }\end{array}$ & $\begin{array}{l}\text { Improved stability; specific targeting of } \\
\text { HCC; good synergistic effect; the tumor } \\
\text { volume and tumor weight of the oxide NPs } \\
\text { treated group reduced to } 60.32 \% \text { and } 60.39 \% \\
\text { compared to the control group, respectively }\end{array}$ \\
\hline $\begin{array}{l}\text { Tang et al. } \\
(2020)[140]\end{array}$ & Liposomes & $\begin{array}{l}\text { Active } \\
\text { targeting }\end{array}$ & Folate receptor (FR) & DOX & $\begin{array}{l}4 \mathrm{~T} 1 \text { cell lines; } \mathrm{H} 22 \text { and Eca9706 } \\
\text { tumor-bearing mice }\end{array}$ & $\begin{array}{l}\text { High drug load capacity; effectively taken } \\
\text { up by cancer cells; no obvious toxicity }\end{array}$ \\
\hline $\begin{array}{l}\text { Hefnawy et al. } \\
\text { (2020) [141] }\end{array}$ & Polymeric NPs & $\begin{array}{l}\text { Active } \\
\text { targeting }\end{array}$ & ASGP-R & DOX & $\begin{array}{l}\text { Hep-G2 cell lines; } \\
\text { HCC-bearing rats }\end{array}$ & $\begin{array}{l}\text { Improved intracellular drug delivery and } \\
\text { uptake; enhanced safety profile; the ability } \\
\text { of the NPs system to enhance the } \\
\text { intracellular uptake of the drug by } 4 \text {-fold } \\
\text { and } 8 \text {-fold after } 4 \mathrm{~h} \text { and } 24 \mathrm{~h} \text { of incubation, } \\
\text { respectively }\end{array}$ \\
\hline
\end{tabular}




\subsection{Lung Cancer}

Lung cancer is an aggressive type of cancer with the highest morbidity and mortality. Lung cancer is divided into small cell lung cancer (SCLC) and NSCLC, of which NSCLC is the most common. Despite the emergence of a variety of treatment methods, there is no denying that chemotherapy is still the dominant clinical treatment for lung cancer, and immunotherapy has emerged as a potent additional treatment against lung cancer [142,143]. However, current treatments for lung cancer have met with limited success, due to the poor targeting of chemotherapeutic drugs, therapeutic resistance, heterogeneity, and the high metastasis of cancer cells [144,145]. Thus, one alternative strategy, active targeting via NPs, has shown promise in the treatment of lung cancer. Previous studies have shown that EGFR up-regulation is often associated with NSCLC, thus EGFR can be used as a targeted molecule to target the delivery of chemotherapy agents [146]. CD44, Sigma, DR 4/5, transferrin, and glucose receptor were also used as a targeted molecule, which can deliver anticancer drugs to tumor cells without harming normal cells $[147,148]$. Besides, CD133 and CD44 were also specific markers for lung cancer-initiating cells [149]. Attempts have been made to deliver chemotherapeutic drugs by exosomes, incorporation of PTX into exosomes (exoPTX) increased cytotoxicity more than 50 times in drug resistant MDCK $\mathrm{MDR}_{\mathrm{M} 1}(\mathrm{Pgp}+$ ) cells. Animal studies have shown that a nearly complete co-localization of airway-delivered exosomes with cancer cells in an LLC mouse model, and a potent anticancer effect in this mouse model [96]. A study reported improved delivery of conventional chemotherapeutics by using QDs that had very low toxicity as nanocarrier [97]. Likewise, a mixed micelle system based on mPEG-SS-PTX and mPEG-SS-DOX conjugate has a significant cytotoxicity to A549 cells [98]. In another study, HA-modified SeNPs loaded with PTX (HA-Se@PTX) displayed significant cellular uptake and controlled release of PTX in vitro [100]. In an attempt to achieve dual-target, Huang and coworkers developed CD133 and CD44 aptamer-conjugated nanomicelles loaded with gefitinib (CD133/CD44-NM-Gef) that were capable of simultaneous targeting to CD44+ and CD133+ lung cancer-initiating cells. CD133/CD44-NM-Gef displayed greater therapeutic efficacy against lung cancer-initiating cells which is crucial for improving therapeutic effects [102]. Recently, a smart PLGA system (PLGA-SS-PEG) loaded with HHT and targeted EGFR has been evaluated in vitro and in vivo, which showed this nanotherapeutic strategy to be safe with better targeting effect. As a targeted nanomedicine, PLGA-SS-PEG is a polymeric drug carrier and targets cancer cells by using an EGFR aptamer [103]. Immunotherapy has become an effective additional therapeutic strategy against lung cancer. Pulmonary surfactant (PS), related to local inflammation and immune response, is abundant in the lung making it different from other organs [150,151]. Pluronic P105 can interact with PS through van der Waals forces and hydrogen bonding [152]. Amphiphilic polymers polyethyleneglycol-polylactic acid (PEG-PLA) and Pluronic P105 were employed as nanocarriers to encapsulate PTX to form into PEG-PLA/P105/PTX micelles. Preclinical studies showed that PEG-PLA /P105/PTX micelles respond to the biological functions of Ax that promotes the secretion of PS and inhibit autophagy, thus modulating the tumor microenvironment to improve drug transportation and cell-killing sensitivity of the micelles [104].

Recently, combinatorial treatment approaches have shown great potential to enhance the therapeutic efficacy, as they better address tumor heterogeneity. A new study was carried out using cell membrane protein-based biomimetic NPs encapsulated DOX and icotinib to EGFR-mutant NSCLC, which achieved high drug accumulation in tumors and enhanced cytotoxicity of the chemotherapeutic drugs. The animal experiment result showed the H1975 cell membrane-coated NPs resulted in $87.56 \%$ tumor inhibition, with the tumor weight 8.75-fold less compared to that of the PBS control group [101]. In another study, DQA modified micelles loaded with PTX and ligustrazine was synthesized to inhibit tumor metastasis. Results showed that the inhibitory effects of DQA modified PTX plus ligustrazine micelles on A549 cell invasion were better than PTX plus ligustrazine micelles. Moreover, DQA modified PTX plus ligustrazine micelles showed the strongest adhesion inhibition and the down-regulation effect on metastasis-related proteins, which proved that the micelles could effectively inhibit the process of tumor metastasis. Improved cellular uptake and drug accumulation in tumor tissue were also observed 
in vivo [99]. Recently, a study was conducted using PTX and GEM-conjugated NLCs on the NSCLC cell lines to determine its efficacy against cancer. In vitro release studies showed that a sequential release of drugs, first PTX (redox-triggered), then GEM (pH-triggered). In addition, this study indicated this nanomedicine achieved a synergistic antitumor effect by targeted intracellularly sequential drug release in vivo [105].

\subsection{Breast Cancer (BC)}

$\mathrm{BC}$ is a highly malignant tumor and the most common cause of death in women [153]. The high death rate of BC suggests that current drug treatments are far from optimal [154]. Generally, breast cancer therapeutic agents are administered intravenously or orally and the drug must pass through many barriers to reach the target tumor [155]. Various chemotherapeutic drugs are used to treat breast tumors; however, some patients do not respond to these products originally designed for general anticancer purposes [156-158]. Reasons for the failure in breast cancer treatment are high heterogeneity, cancer cells use drug delivery pumps to throw away the drugs which are inside the cell, metastasis that is not affected by drugs, and stem cells develop resistance to chemotherapy $[159,160]$.

This disease is defined by the expression of estrogen, progesterone, and HER-2 [161]. Breast cancer cell receptors play a strong part in the treatment of this disease, as it forms the basis of a targeted strategy for treatment. Besides HER-2, some other molecular targets have been used in the active targeting of BC. An important receptor is the EGFR overexpressed in up to half of the BC cases and has a high density on the cell surface [162]. FR is also common targets for drug delivery, as FR is expressed in $50-86 \%$ of metastatic TNBC patients who generally have poorer prognosis [163]. Transferrin receptors, Fn14, estrogen receptors (ERs), and CXC chemokine receptor type 4 (CXCR-4) are also used in a targeted strategy for treatment [164-167]. Han et al. fabricated PEG long-circulating liposomes loaded with PTX for targeting ERs in breast cancer. The liposome formulation can effectively target, quickly, and specifically identify the tumor site, and prolong drug action time [116]. Targets of breast cancer stem cells (BCSCs) include CD44 and CD133 receptor [168,169]. Besides anti-CD44 monoclonal antibodies, several nano-delivery systems have been developed to target CD44 receptors using different targeting moieties, such as HA [168]. In recent years, with an in-depth understanding of the molecular biology of BC, a number of promising nano-therapeutic strategies have been developed [170]. In a study, pegylated PTX nanocrystals (PEG-PTX-NCs) were prepared and the antitumor efficacy of PEG-PTX-NCs was investigated. The animal experiment results showed that PEG-PTX-NCs significantly enhanced the antitumor effect in treating in situ tumor or metastatic tumor bearing mice after intravenous administration [106]. In another study, the efficacy of cisplatin loaded into ultra-short single-walled CNTs capsules was investigated in vivo. Results indicated that this nanodrug showed a prolonged circulation time compared to free cisplatin which EPR effects resulting in significantly more cisplatin accumulation in tumors [107]. Recent research has reported the use of plant viral NPs for delivering DOX. The finding suggested that DOX-loaded viral NPs were effective in MDA-MB-231 cells although at lower efficacy than free DOX [109]. Additionally, a study investigating the efficiency of DOX loaded SiNPs (SiNPs/DOX). Findings showed that the SiNPs/DOX improved the efficiency of cellular drug delivery, exhibited high cytotoxicity, and successfully inhibited the tumor growth [110]. In another study, the researchers reported that a cross-linked multifunctional polymeric NPs loaded with DTX (DTX-CMHN) showed significantly better inhibition of primary 4T1-Luc tumor growth and lung metastasis with little body weight loss compared to the free DTX group in vivo [112]. Difficulty in eradicating cancer stem cells (CSCs) is another main cause of failure in the BC treatment. Fortunately, multiple studies have shown that dual-drugs (PTX, DOX, 5-fluorouracil (5-Fu) and dexamethasone) simultaneously loaded NPs are effective against BC stem cells. Findings suggested that the dual-DDS, especially carcinogenic drugs in combination with plant and other natural source compounds, has better effects with reduced toxicity in the treatment of BC [160]. In addition, salinomycin-loaded PLNs anti-HER2 NPs (Sali-NP-HER2) were developed to target both HER-2-positive BCSCs and cancer 
cells. The study indicated Sali-NP-HER2 efficiently targeted to HER2-positive BCSCs and cancer cells, resulting in enhanced efficiency compared with non-targeted NPs or salinomycin [108].

The emergence of resistance to chemotherapy in $\mathrm{BC}$ is one of the major obstacles to achieve the success of $B C$ treatment. To address drug-resistant $B C$, an arginine-glycine-aspartic (RGD) tripeptide coated, $\mathrm{pH}$-sensitive SLNs (RGD-DOX-SLNs) were employed to load DOX. RGD-DOX-SLNs showed a higher area under the plasma concentration-time curve and peak concentration compared to DOX solution with no obvious toxicity on cell [111]. Likewise, a liposomal co-delivery system co-loaded with DOX and poria cocos extract was prepared. Results indicated that DOX and poria cocos extract synergistically reversed multi-drug resistance (MDR) during tumor treatment with decreased cardiac toxicity [113]. In another study, a new polymeric micelle composed of phenylboric acid (PBA)-modified F127 (active-targeting group) and DOX-grafted P123 (prodrugs group) (FBP-CAD) was designed for enhancing tumor MDR reversal and chemotherapy efficiency in BC. Results revealed that FBP-CAD micelles possessed stronger cell-killing capacity in vitro, and specifically accumulated at the tumor site with decreased cardiotoxicity in vivo [118].

It is well known that EPR can enhance targeted drug delivery especially for solid tumors (e.g., BC). Without any specific receptor target, the nanocarrier $(<100 \mathrm{~nm}$ in diameter) can penetrate the cells at the cancerous site through endocytosis, increasing the availability of drugs acting on intracellular organelles. Through EPR, nanocarriers have enhanced the anticancer effects of PTX and DOX, since nanocarriers can passively enter cancer cells and act on intracellular targets [165]. In the latest study, DOX is loaded into the zeolitic imidazolate framework, leading to effective drug accumulation in tumors due to the EPR effect and precise release of the drug in the tumor site by its $\mathrm{pH}$ sensitive instability with no side effects to the normal tissue [114].

In addition, the efficacy can also be enhanced by binding active target ligands on the particle surface, increasing tumor selection, and tumor cell-specific uptake drug. In one study, a PTX loaded nanoscale polymer was designed to specifically target the cell surface receptor Fn14. Targeting to Fn14 enhanced the inhibition of breast tumors and significantly minimized the nonspecific binding to blood serum proteins and tumor tissue components [115]. Another study reported an RNA four-way junction NPs with ultra-thermodynamic stability covalently loaded with high-density PTX (RNA-PTX) for targeted cancer therapy. Results showed that RNA-PTX dramatically strongly accumulated in tumors and inhibited tumor growth with negligible toxicity in vivo [91]. Zafar and its associates developed pegylated LNCs for co-encapsulation of DTX and thymoquinone (THQ). The in vivo tumor growth inhibition study showed that the average tumor volume was lowest for the pegylated nanocapsules treated group compared to the control group and free DTX treated group, which confirmed the anti-cancer superiority of the dual drug-loaded nanocapsules. In addition, the formulation showed a remarkable reduction in toxicities associated with the liver, kidney, and oxidative stress [117].

\subsection{Pancreatic Cancer (PC)}

$\mathrm{PC}$ is one of the most lethal solid malignancies, mainly due to its dense fibrotic stroma, high metastasis, and highly immunosuppressive tumor microenvironment limiting the therapeutic efficacy of available chemotherapeutics and has low cure rate [171]. The desmoplasia of the stroma of PC takes up most of the tumor mass ( $80 \%$ or more), leading to abnormal vascularization, high intratumoral pressure, and poor drug diffusion [172]. Therapeutic agents administered intravenously must first extravasate and pass through a thick, fibrous tissue to locate a tumor target, thus therapeutic efficacy is limited. High frequency of genomic changes seen in PC results in significant genomic instability and loss of their suppressor functions, reducing response to treatment [173]. There is an intricate network of signaling and genetic alternations and cross talk between cells and microenvironment that make it harder to treat.

Standard chemotherapeutic agents have been used to treat PC include GEM, 5-Fu, leucovorin, irinotecan, oxaliplatin, cisplatin, and capecitabine. Among them, GEM is the frontline drug for treating PC, but it is only effective in $23.8 \%$ of these cases [174]. Other drugs are also used for treating PC, 
including Abraxane ${ }^{\circledR}$, Onyvide ${ }^{\circledR}$, and so on. As the vast majority of patients suffering from PC prefers to chemotherapy, novel and effective chemotherapy drugs are urgently needed.

In order to ensure a high-affinity interaction with cancer cells, antibodies, or receptor agonists were coated to the surface of the nanocarrier. The expression of several surface receptors, such as targeting transferrin receptors, FR, EGFR, Lf receptors, vascular endothelial growth factor (VEGF), and HA receptors, has been associated with the progression of PC [175-178]. In another study, the tumor homing peptide tLyp1 functionalized HA nanocapsules loaded with DTX, which dual-targeted tumors and the lymphatics. In vitro study showed these nanocapsules could interact with the NRP1 receptors over-expressed in cancer cells. The results showed a dramatic accumulation of DTX in the tumor and a reduction of the tumor [119]. Accordingly, a poly-L-lysine coated PTX loaded PLGA NPs formulation showed the inhibition of tumor growth and anti-metastasis against PC [122]. To eliminate pancreatic CSCs for preventing metastasis, Lf and HA double-coated lignosulfonate (LS) based nanosystem was developed to target Lf receptors on cancer cells and CD44 receptor overexpressed in tumor and pancreatic CSCs. After loading QC, the nanomedicine showed the great inhibition of migration and invasion of PANC-1 cells in vitro and tumor volume reduction in vivo [125].

In addition, the therapeutic effect of PC will be improved from combined treatment. In a study related to the use of liposomes in drug delivery, Lin et al. investigated the effect of GE-11 peptide conjugated liposome loaded with GEM and HIF1 $\alpha$-siRNA (GE-GML/siRNA) on PCCs. According to the results of the experiment, the designed GE-GML/siRNA increased the intracellular concentrations in the cancer cells and showed a significant reduction in the tumor burden. Furthermore, a synergistic combination of GEM and HIF1 $\alpha$-siRNA significantly inhibited cancer cell proliferation [120]. Inspired by this result, ultra-small pegylated NDs loaded with irinotecan and curcumin (ND-IRT + CUR) were studied, and it exhibited superior anti-tumor effects in vivo in two different mouse models of aggressive PC [123].

Regulating the surface hydrophilicity of nanocarriers can prevent them from being eliminated by macrophages, thus prolonging the drug circulation time in the body. The most common modifications are PEG, poloxamers, polysaccharides, and other hydrophilic polymers. In the latter study, PEG-functionalized NDs loaded with DOX (ND-PEG-DOX) displayed excellent biocompatibility and prolonged drug retention in vivo [121]. According to Elechalawar et al., gold NPs were used for targeted delivery of GEM to PCCs with the monoclonal antibody cetuximab (C225) as the targeting ligand for EGFR and PEG as a stealth molecule. As a result, enhanced selectivity towards PCCs and pancreatic stellate cells (PSCs) was observed in vitro [126].

The highly immunosuppressive tumor microenvironment and dense fibrotic stroma barrier are the two major obstacles for achieving great therapeutic efficacy. In order to solve this problem, a study has reported that a redox-responsive GEM-conjugated polymer (PGEM) co-loaded with PTX and NLG919 showed deeper penetration in PC tumor tissues. In vivo studies suggested that incorporation of NLG919 into the nanomedicine reversed indoleamine 2, 3-dioxygenase (IDO)-mediated immunosuppression, and thereby enhanced the therapeutic effect [124]. In another study, an innovative combination of metformin (MET) with pHLIP co-modified $\mathrm{Fe}_{3} \mathrm{O}_{4}$ NPs loaded with GEM has been investigated. MET was firstly administrated to destroy the dense fibrotic stroma barrier, which improved the delivery efficiency of GEM in vivo. Findings suggested that targeted delivery and effective accumulation of the nanomedicine both in vitro and in vivo. Furthermore, the configuration change of pHLIP is controlled by the acidic environment of the tumor, which is beneficial to deliver GEM into the tumor sites [127].

\subsection{Glioblastoma (GBM)}

GBM is the most angiogenic and highly lethal brain tumor, treatment of gliomas is still difficult to achieve satisfying outcomes, as the inability to achieve therapeutic agent concentrations at the tumor tissue. In addition to the genetic and signaling heterogeneity, the BBB and blood-brain tumor barrier (BBTB), known as the major obstacles, make therapy greatly inefficient. 
In GBM, the nanomedicines have to be able to cross or bypass the BBB, and at the same time must not cause an immune response [179]. Among these different nanocarriers, polymers have met the strict requirements required for biological applications. For instance, Meng et al. found that a borneol-modified nanomicelle loaded with DOX exhibited superior transport efficiency of DOX across the BBB and accumulation in the brain tissues [131]. Likewise, a study suggested the usage of positively charged chitosan-coated pegylated NPs for co-delivery of R-flurbiprofen and PTX to glioma tissue. It was shown that this PLGA NPs are able to carry their payloads to glioma tissue, enhance the anti-tumor activity, and reduce inflammation in the peri-tumoral area [134].

A more recent approach for increasing anti-glioma efficacy and safety involves the use of a dual-targeting glioma DDS to increase the accumulation at the glioma site after effectively crossing the $\mathrm{BBB}$ and BBTB. An example of a receptor-ligand targeting subset of active DDS is the TfR1. A dualtargeted delivery system (GKRK-APO) made of APO and GKRK peptide ligand, increases the specific targeting to brain endothelial cells and glioma cells and displayed higher glioma localization. Based on the results of the experiments, it has been demonstrated that GKRK-APO loaded with VCR efficiently overcame multiple barriers (e.g., BBB and BBTB) and showed an effective anti-glioma effect in vitro and in vivo [128]. Another study relates to the Pep-1\&borneol-bifunctionalized CMS-loaded micelles (Pep1/Bor/CMS-M) was able to target interleukin-13 receptor overexpressed glioma and penetrate BBB. In addition, it showed that Pep1/Bor/CMS-M enhanced CMS accumulation in glioma, suppressed the tumor growth, and improved the survival period with low systemic toxicity [129]. It is known that CSCs play an important role in the development and metastasis of tumors and as a barrier against the anticancer effects of chemotherapeutic drugs. Thus, a DDS could significantly enhance anti-cancer efficacy by precisely targeting to both cancer cells and CSCs after effectively crossing the BBB. Recently, it has been reported that SKN and DTX co-loaded nanoemulsion bifunctionalized with AS1411 aptamer, and HA penetrated the BBB, inhibited tumor growth, and prolonged the survival period in vivo. The nanoemulsion was accurately delivered to the glioma region through the high affinity between HA and CD44 receptor, AS1411 and nucleolin, and SKN reduced the population of CSCs [132]. Another study showed that IGU loaded PLGA NPs (IGU-PLGA-NPs) were able to improve therapeutic outcomes in glioma, glioma stem-like cells, and temozolomide resistant glioma cells. It demonstrated not only significant inhibition of glioma cells proliferation both in vitro and in vivo but also anti-migration in glioma cells with low systemic toxicity [133].

Cell membrane-covered nanocarriers are also attractive delivery platforms. A recent study achieved DOX-Lex dual-drug delivery via angiopep-2 functionalized red blood cell membranes camouflaged NPs. The nanosystem showed prolonged blood circulation, superior BBB penetration, improved accumulations at the glioma site, and reduced tumor growth [130].

\subsection{Hepatocellular Carcinoma (HCC)}

HCC, the most frequent type of liver cancer, is a typical hyper-vascular tumor and shows a poor response to current conventional drug treatments [180]. In addition, more than ninety percent of patients relapse after treatment, which mainly accounts for the morbidity.

Surface molecules that are only highly expressed on the surface of hepatocytes and hepatocellular carcinoma cells, such as ASGP-R and glycyrrhetinic acid (GA) receptor, can be used as targets for nanodrugs delivery to increase cellular uptake. Thus, galactose residues were frequently used to modify the surfaces of NPs for selective hepatic delivery, due to their binding affinity to ASGP-R. Currently, the research of HCC targeting DDS is primarily focused on single ligand-modified polymeric NPs. For example, galactosylated chitosan NPs loaded with TP (GC-TP-NPs) were prepared and assessed in vitro and in vivo. GC-TP-NPs cellular uptake was greater than free TP in vitro and accumulated preferentially in the liver tumor in vivo. GC-TP-NPs were taken up by SMMC-7721 cells more than the non-modified NPs, indicating ASGP-R mediated endocytosis accelerated its uptake. Moreover, the TP is released from GC-TP-NPs in a sustained manner, which may contribute to maintaining higher TP concentrations for long periods at the tumor sites [135]. Dual or multiple coating of nanocarriers for 
increased efficiency and selectivity of the targeting delivery is also an interesting therapeutic trend. Accordingly, a dual-ligand system, 18 $\beta$-GA and lactobionic acid (LA)-modified chitosan NPs loaded with DOX, displayed enhanced intracellular uptake of the drug. In vivo and in vitro studies also proved that the developed system showed an enhanced safety profile [141].

Besides, there have been also several attempts to treat HCC by co-loading dual drugs into a single nanocarrier. Dual DDS is being investigated to deliver Sf, which is the only available systemic drug for HCC. The combined therapy of $\mathrm{pH}$-sensitive carboxymethyl chitosan-coated liposomes for delivery of Sf and siRNA against vascular endothelial growth factor (VEGF-siRNA) was found to significantly enhanced VEGF downregulating effect, inducing cell early apoptosis, as compared to free siRNA and single loaded carrier [136].

Researchers also investigated simultaneously encapsulating molecular inhibitors and standard cytotoxic chemotherapeutics within a single nanocarrier. Apa and pSN38 co-loaded NPs were formulated using mPEG5k-PLA8k, the clinically approved amphiphilic copolymer, for sequential delivery of both encapsulated drugs to HCC. Results indicated that stable NPs realized the sequential release of both encapsulated drugs to exert antimetastatic, antivascular, and cytotoxic activities simultaneously and reduced drug resistance [137]. CD44-targeted HA-conjugated Janus nanocarrier (HA-MSN@DB) for delivery of DOX and BER was found to significantly enhanced the antitumor activity of DOX and suppressed DOX-exacerbated HCC repopulation in vitro and in vivo. In addition, it was reported that the nanomedicine exhibited better intracellular internalization and favorable tumor accumulation [138]. In another study, the researchers used PEG-graft-polyglutamic acid (PEG-PLG) and HA-decorated NPs to simultaneously encapsulate DOX and diethyldithiocarbamate-copper complex $\left(\mathrm{Cu}(\mathrm{DDC})_{2}\right)$ to achieve the selective co-delivery of the drug to HCC cells. It is worth noting that $\mathrm{Cu}(\mathrm{DDC})_{2}$ was not only an effective component for cancer therapy but also the composition of carrier materials. The NPs significantly improved the delivery of drugs to HCC cells, resulting in greater cellular uptake in HepG2 cells. At the same time, the results indicated the targeted NPs showed good synergistic effect and inhibited tumor growth in vivo [139]. In a recent study, lipids extracted from egg yolks have been used to prepare nano-sized particles. Application of folic acid (FA)-modified natural egg yolk lipid nanovector (EYLNs) load with DOX (FA-EYLNs-DOX) showed higher encapsulation efficiency and were effectively taken up by cancer cells without obvious toxicity in vitro and in vivo. In addition, FA-EYLNs-DOX showed that FA significantly achieved better tumor targeting of EYLNs-DOX [140].

Although many nanomaterials are currently in preclinical development, the number of nanomaterials in clinical trials and approved for clinical use is still low. Nanoformulations developed for selected solid tumors under clinical trials are summarized in Table 3. The formulations are mostly based on liposomes, polymeric NPs, and NP albumin-bound PTX (Abraxane ${ }^{\circledR}$ ). In preclinical practice, nanodrugs generally increase tumor growth inhibition and prolong survival compared with non-formulated drugs, but in clinical settings, patients tend to benefit from nanomedicines due to reduced or altered side effects. Most clinically approved cancer nanomedicines are based on standard cytostatics, such as DOX, daunorubicin, PTX, VCR, and irinotecan [181]. Liposomal irinotecan (Onivyde ${ }^{\circledR}$ ) has recently been approved in combination with 5-FU and leucovorin for the treatment of PC [182]. Abraxane ${ }^{\circledR}$ combined with the immune checkpoint inhibitor atezolizumab, another promising systemic combination therapy, together induced unprecedented therapeutic responses in patients with triple negative BC [183]. Inspired by these results, recent clinical trials have tried to incorporate nanomedicines in systemic combination therapies. Suffice it to say, these preclinical studies manifest that there is no lack of innovative ideas and platforms for targeted drug delivery. 
Table 3. A list of recent clinical trials of nanomedicines for the treatment of selected solid tumors.

\begin{tabular}{|c|c|c|c|c|c|c|}
\hline $\begin{array}{c}\text { Particle Type/ } \\
\text { Therapeutic Agent }\end{array}$ & Treatments & Cancer Subtypes & $\begin{array}{l}\text { Trial Starting } \\
\text { Date }\end{array}$ & Phase & Aim of the Study & NCT Number \\
\hline ABI-009 (nab-Rapamycin) & Combination therapy & GBM & Aug. 2018 & II & $\begin{array}{l}\text { ABI-009 will be tested as single agent or in combination } \\
\text { with standard therapies }\end{array}$ & NCT03463265 \\
\hline Abraxane $^{\circledR}$ & Combination therapy & $\begin{array}{l}\text { pancreatic ductal } \\
\text { adenocarcinoma (PDA) }\end{array}$ & Jul. 2018 & II & $\begin{array}{l}\text { To compare the first-line treatment with nab-PTX plus S-1 } \\
\text { and nab-PTX plus GEM in advanced PDA with primary } \\
\text { tumor nonexcision in Chinese patients }\end{array}$ & NCT03636308 \\
\hline Abraxane ${ }^{\circledR}$ & Combined with CPT & HER-2 Negative BC & Nov. 2018 & IV & $\begin{array}{l}\text { To evaluate of the efficacy and safety of nanoparticle } \\
\text { albumin-bound PTX combined with CPT as neoadjuvant } \\
\text { chemotherapy in luminal B/HER-2 negative BC }\end{array}$ & NCT03799692 \\
\hline Abraxane ${ }^{\circledR}$ & $\begin{array}{l}\text { Combined with } \\
\text { Epirubicin and } \\
\text { Cyclophosphamide }\end{array}$ & TNBC & Nov. 2018 & IV & $\begin{array}{l}\text { To evaluate of the efficacy and safety of weekly Nab-P } \\
\text { followed by dose-intensive epirubicin in combination with } \\
\text { cyclophosphamide as neoadjuvant chemotherapy in TNBC }\end{array}$ & NCT03799679 \\
\hline $\begin{array}{l}\text { Pegylated liposomal DOX } \\
\text { (PLD) }\end{array}$ & $\begin{array}{l}\text { Combined with } \\
\text { trastuzumab }\end{array}$ & HER2-positive BC & Mar. 2019 & II & $\begin{array}{l}\text { To evaluate the efficacy and safety of PLD in combination } \\
\text { with trastuzumab in HER-2 positive metastatic BC }\end{array}$ & NCT03933319 \\
\hline $\begin{array}{l}\text { Pegylated Liposomal DOX } \\
\text { (Doxil/Caelyx) }\end{array}$ & $\begin{array}{l}\text { Combined with } \\
\text { pembrolizumab } \\
\text { (Keytruda) }\end{array}$ & $\begin{array}{l}\text { Metastatic } \\
\text { Endocrine-resistant BC } \\
\text { (ERBC) }\end{array}$ & Apr. 2019 & $\mathrm{I} / \mathrm{II}$ & $\begin{array}{l}\text { To evaluate the tumor response and appropriate dose of a } \\
\text { chemo-immunotherapy regime consisting of treatment } \\
\text { with PLD and pembrolizumab-based in ERBC patients }\end{array}$ & NCT03591276 \\
\hline $\begin{array}{l}\text { QDs coated with } \\
\text { veldoreotide }\end{array}$ & Monotherapy & $\mathrm{BC}$ & Sep. 2019 & I & $\begin{array}{l}\text { A novel formulation for treatment and bioimaging of } \mathrm{BC} \\
\text { which can deliver safely to the patients in a high dose to } \\
\text { the affected tumor cells }\end{array}$ & NCT04138342 \\
\hline $\begin{array}{l}\text { Pegylated liposomal DOX } \\
\text { (PLD) }\end{array}$ & $\begin{array}{l}\text { Combined with } \\
\text { albumin-bound PTX } \\
\text { and trastuzumab }\end{array}$ & HER-2 positive BC & Oct. 2019 & $\mathrm{I} / \mathrm{II}$ & $\begin{array}{l}\text { To evaluate the efficacy and safety of PLD plus } \\
\text { Albumin-Bound PTX and trastuzumab as neoadjuvant } \\
\text { therapy in HER-2 positive BC }\end{array}$ & NCT03994107 \\
\hline Abraxane ${ }^{\circledR}$ & Combined with CPT & TNBC & Dec. 2019 & III & $\begin{array}{l}\text { This trial will compare the therapeutic effect of } \\
\text { albumin-bound PTX with solvent-based PTX in TNBC } \\
\text { patients, and seek for important scientific clues, scientific } \\
\text { evidence, and clinical data for nab-P in the } \\
\text { treatment of TNBC }\end{array}$ & NCT04137653 \\
\hline PTX liposome & Combined with S-1 & Advanced PC & Jan. 2020 & IV & $\begin{array}{l}\text { To investigate the efficacy and safety of the patients with } \\
\text { confirmed advanced PC after treating with the } \\
\text { combination of PTX liposome plus S-1 }\end{array}$ & NCT04217096 \\
\hline Abraxane ${ }^{\circledR}$ & $\begin{array}{l}\text { Combined with } \\
\text { Alpelisib }\end{array}$ & TNBC & Feb. 2020 & II & $\begin{array}{l}\text { To determine if alpelisib in combination with nab-PTX will } \\
\text { improve treatment effect of patients with chemotherapy } \\
\text { insensitive TNBC }\end{array}$ & NCT04216472 \\
\hline $\begin{array}{l}\text { Liposomal irinotecan } \\
\text { (nal-IRI) }\end{array}$ & $\begin{array}{l}\text { Combined with } \\
\text { Oxaliplatin, } \\
\text { Leucovorin, and 5-Fu }\end{array}$ & $\begin{array}{l}\text { Locally Advanced } \\
\text { Pancreatic Carcinoma } \\
\text { (LAPC) }\end{array}$ & Mar. 2020 & II & $\begin{array}{l}\text { To investigate the efficacy and tolerability of a combination } \\
\text { of liposomal irinotecan (nal-IRI) with oxaliplatin, } \\
\text { leucovorin, and 5-Fu (FOLFOX-nal-IRI) for treatment of } \\
\text { patients with LAPC }\end{array}$ & NCT03861702 \\
\hline
\end{tabular}


Table 3. Cont

\begin{tabular}{|c|c|c|c|c|c|c|}
\hline $\begin{array}{c}\text { Particle Type/ } \\
\text { Therapeutic Agent }\end{array}$ & Treatments & Cancer Subtypes & $\begin{array}{c}\text { Trial Starting } \\
\text { Date }\end{array}$ & Phase & Aim of the Study & NCT Number \\
\hline $\begin{array}{l}\text { Liposome-entrapped } \\
\text { mitoxantrone hydrochloride } \\
\text { injection (PLM60) }\end{array}$ & Monotherapy & Advanced HCC & Apr. 2020 & I & $\begin{array}{l}\text { To evaluate the safety and efficacy of PLM60 in } \\
\text { advanced HCC }\end{array}$ & NCT04331743 \\
\hline
\end{tabular}

May 2020. 


\section{Conclusions}

With the development of nanocarriers, the versatility of NPs enables them to promote drug synergy under precise control of drug distribution in space and time with the aim of reducing the risk of drug resistance and targeting different types of cancer. Many biocompatible nanometer material carriers have been studied and conjugated with multiple active pharmaceutical ingredients. However, with the increased complexity of the nanoformulation, it probably leads to higher toxicity, increased manufacturing cost, and manufacturing practice issues. More advanced technologies are needed to assess the interactions between nanomedicines and biological systems [184]. In addition, the loading concentration and encapsulation efficiency of active drugs, the two basic parameters used to evaluate nanocarriers, may be also the main disadvantages of some NPs delivery platforms. For instance, liposomes have a low encapsulate rate and a short releasing time [185]. More importantly, the rational combination of multiple drugs with different modes-of-action is also a challenge, since most DDS simply mixes different drugs together to co-administration, regardless of pharmacokinetics and distribution in tumor sites. In addition, when the NPs come into contact with live cells in vivo, proteins immediately covers the surface of the nanomaterials, affecting cell uptake, inflammation, accumulation, and degradation of NPs [186]. A great many nanocarriers have been developed, which establishes the foundation for its clinical translation. But while nanocarriers have many advantages, only a few of them have been approved by the FDA [187]. The accurate identification of patients suitable for clinical trial research, an in-depth understanding of their mechanisms of action, and the establishment of effective academic-industrial partnerships at all stages of drug development is important for the successful transition of new nanocarriers from pre-clinical to clinical. There are also several obvious challenges on the commercial and industrial scale, including reproducibility, non-uniform size, irregular structure/shape, sterilization, and storage for mass production [188]. The accumulation of nanodrugs in unwanted tissues and organs results in long-term toxicity problems. Therefore, in preclinical and clinical studies, the determination of the biological distribution of NPs after systemic administration should be considered.

Although there are still uncertain safety concerns of these nanomaterials, the current findings strongly suggested that nanomaterials have a promising future in the field of solid tumor treatment. In order to render nanocarriers preferably adaptable in vivo to the complex environment, more reasonable strategies for combining chemotherapy drugs, nanocarriers, and targeting moieties need to be developed.

Author Contributions: Writing—original draft preparation, Q.-Y.W., Y.-M.X. and A.T.Y.L.; writing—review and editing, Q.-Y.W., Y.-M.X. and A.T.Y.L.; supervision, Y.-M.X. and A.T.Y.L.; funding acquisition, Y.-M.X. and A.T.Y.L. All authors have read and agreed to the published version of the manuscript.

Funding: This work was supported by the grants from the National Natural Science Foundation of China (Nos. 31771582 and 31271445), the Guangdong Natural Science Foundation of China (No. 2017A030313131), the "Thousand, Hundred, and Ten" project of the Department of Education of Guangdong Province of China, the Basic and Applied Research Major Projects of Guangdong Province of China (2017KZDXM035 and 2018KZDXM036), and the "Yang Fan" Project of Guangdong Province of China (A.T.Y.L.-2016; Y.-M.X.-2015).

Acknowledgments: We would like to thank members of the Lau and $\mathrm{Xu}$ laboratory for critical reading of this manuscript.

Conflicts of Interest: The authors declare no conflict of interest.

\section{References}

1. Mujokoro, B.; Adabi, M.; Sadroddiny, E.; Adabi, M.; Khosravani, M. Nano-structures mediated co-delivery of therapeutic agents for glioblastoma treatment: A review. Mater. Sci. Eng. C 2016, 69, 1092-1102. [CrossRef] [PubMed]

2. McGowan, J.V.; Chung, R.; Maulik, A.; Piotrowska, I.; Walker, J.; Yellon, D.M. Anthracycline Chemotherapy and Cardiotoxicity. Cardiovasc. Drugs Ther. 2017, 31, 63-75. [CrossRef]

3. Probst, C.E.; Zrazhevskiy, P.; Bagalkot, V.; Gao, X. Quantum dots as a platform for nanoparticle drug delivery vehicle design. Adv. Drug Deliv. Rev. 2013, 65, 703-718. [CrossRef] [PubMed] 
4. Peer, D.; Karp, J.M.; Hong, S.; Farokhzad, O.C.; Margalit, R.; Langer, R. Nanocarriers as an emerging platform for cancer therapy. Nat. Nanotechnol. 2007, 2, 751-760. [CrossRef] [PubMed]

5. Hyodo, K.; Yamamoto, E.; Suzuki, T.; Kikuchi, H.; Asano, M.; Ishihara, H. Development of liposomal anticancer drugs. Biol. Pharm. Bull. 2013, 36, 703-707. [CrossRef] [PubMed]

6. Maeda, H.; Nakamura, H.; Fang, J. The EPR effect for macromolecular drug delivery to solid tumors: Improvement of tumor uptake, lowering of systemic toxicity, and distinct tumor imaging in vivo. Adv. Drug Deliv. Rev. 2013, 65, 71-79. [CrossRef]

7. Fang, J.; Nakamura, H.; Maeda, H. The EPR effect: Unique features of tumor blood vessels for drug delivery, factors involved, and limitations and augmentation of the effect. Adv. Drug Deliv. Rev. 2011, 63, 136-151. [CrossRef]

8. Rosenblum, D.; Joshi, N.; Tao, W.; Karp, J.M.; Peer, D. Progress and challenges towards targeted delivery of cancer therapeutics. Nat. Commun. 2018, 9, 1410. [CrossRef]

9. Bar-Zeev, M.; Livney, Y.D.; Assaraf, Y.G. Targeted nanomedicine for cancer therapeutics: Towards precision medicine overcoming drug resistance. Drug Resist. Updat. 2017, 31, 15-30. [CrossRef]

10. Danhier, F. To exploit the tumor microenvironment: Since the EPR effect fails in the clinic, what is the future of nanomedicine? J. Control. Release 2016, 244, 108-121. [CrossRef]

11. Gharpure, K.M.; Wu, S.Y.; Li, C.; Lopez-Berestein, G.; Sood, A.K. Nanotechnology: Future of oncotherapy. Clin. Cancer Res. 2015, 21, 3121-3130. [CrossRef] [PubMed]

12. Van Rijt, S.H.; Böluükbas, D.A.; Argyo, C.; Datz, S.; Lindner, M.; Eickelberg, O.; Königshoff, M.; Bein, T.; Meiners, S. Protease-mediated release of chemotherapeutics from mesoporous silica nanoparticles to ex vivo human and mouse lung tumors. ACS Nano 2015, 9, 2377-2389. [CrossRef]

13. Taratula, O.; Kuzmov, A.; Shah, M.; Garbuzenko, O.B.; Minko, T. Nanostructured lipid carriers as multifunctional nanomedicine platform for pulmonary co-delivery of anticancer drugs and siRNA. J. Control. Release 2013, 171, 349-357. [CrossRef] [PubMed]

14. Torchilin, V.P. Multifunctional, stimuli-sensitive nanoparticulate systems for drug delivery. Nat. Rev. Drug Discov. 2014, 13, 813-827. [CrossRef]

15. Leucuta, S.E. Nanotechnology for delivery of drugs and biomedical applications. Curr. Clin. Pharmacol. 2010, 5, 257-280. [CrossRef] [PubMed]

16. Buse, J.; El-Aneed, A. Properties, engineering and applications of lipid-based nanoparticle drug-delivery systems: Current research and advances. Nanomedicine 2010, 5, 1237-1260. [CrossRef]

17. Akbarzadeh, A.; Rezaei-Sadabady, R.; Davaran, S.; Joo, S.W.; Zarghami, N.; Hanifehpour, Y.; Samiei, M.; Kouhi, M.; Nejati-Koshki, K. Liposome: Classification, preparation, and applications. Nanoscale Res. Lett. 2013, 8, 102. [CrossRef]

18. Bulbake, U.; Doppalapudi, S.; Kommineni, N.; Khan, W. Liposomal formulations in clinical use: An updated review. Pharmaceutics 2017, 9, 12. [CrossRef]

19. Stone, N.R.H.; Bicanic, T.; Salim, R.; Hope, W. Liposomal amphotericin B (AmBisome ${ }^{\circledR}$ ): A review of the pharmacokinetics, pharmacodynamics, clinical experience and future directions. Drugs 2016, 76, 485-500. [CrossRef]

20. Wissing, S.A.; Kayser, O.; Müller, R. Solid lipid nanoparticles for parenteral drug delivery. Adv. Drug Deliv. Rev. 2004, 56, 1257-1272. [CrossRef]

21. Cai, S.; Yang, Q.; Bagby, T.R.; Forrest, M.L. Lymphatic drug delivery using engineered liposomes and solid lipid nanoparticles. Adv. Drug Deliv. Rev. 2011, 63, 901-908. [CrossRef] [PubMed]

22. Fang, C.L.; Al-Suwayeh, S.A.; Fang, J.Y. Nanostructured lipid carriers (NLCs) for drug delivery and targeting. Recent Patents Nanotechnol. 2013, 7, 41-55. [CrossRef]

23. Yang, Y.; Corona, A.; Schubert, B.; Reeder, R.; Henson, M.A. The effect of oil type on the aggregation stability of nanostructured lipid carriers. J. Colloid Interface Sci. 2014, 418, 261-272. [CrossRef] [PubMed]

24. Husseini, G.A.; Pitt, W.G. Micelles and nanoparticles for ultrasonic drug and gene delivery. Adv. Drug Deliv. Rev. 2008, 60, 1137-1152. [CrossRef]

25. Palazzolo, S.; Bayda, S.; Hadla, M.; Caligiuri, I.; Corona, G.; Toffoli, G.; Rizzolio, F.; Palazzolo, S.B.S. The clinical translation of organic nanomaterials for cancer therapy: A focus on polymeric nanoparticles, micelles, liposomes and exosomes. Curr. Med. Chem. 2018, 25, 4224-4268. [CrossRef]

26. Gothwal, A.; Khan, I.; Gupta, U. Polymeric micelles: Recent advancements in the delivery of anticancer drugs. Pharm. Res. 2016, 33, 18-39. [CrossRef] 
27. Li, W.; Huang, L.; Ying, X.; Jian, Y.; Hong, Y.; Hu, F.; Du, Y.Z. Antitumor drug delivery modulated by a polymeric micelle with an upper critical solution temperature. Angew. Chem. Int. Ed. 2015, 54, 3126-3131. [CrossRef] [PubMed]

28. Cabral, H.; Matsumoto, Y.; Mizuno, K.; Chen, Q.; Murakami, M.; Kimura, M.; Terada, Y.; Kano, M.R.; Miyazono, K.; Uesaka, M.; et al. Accumulation of sub-100 nm polymeric micelles in poorly permeable tumours depends on size. Nat. Nanotechnol. 2011, 6, 815-823. [CrossRef]

29. Thakor, A.S.; Gambhir, S. Nanooncology: The future of cancer diagnosis and therapy. CA Cancer J. Clin. 2013, 63, 395-418. [CrossRef]

30. Duncan, R.; Vicent, M.J. Polymer therapeutics-prospects for 21st century: The end of the beginning. Adv. Drug Deliv. Rev. 2013, 65, 60-70. [CrossRef]

31. Herrero, E.; Fernandez-Medarde, A. Advanced targeted therapies in cancer: Drug nanocarriers, the future of chemotherapy. Eur. J. Pharm. Biopharm. 2015, 93, 52-79. [CrossRef] [PubMed]

32. Li, H.; Lee, T.; Dziubla, T.; Pi, F.; Guo, S.; Xu, J.; Li, C.; Haque, F.; Liang, X.-J.; Guo, P. RNA as a stable polymer to build controllable and defined nanostructures for material and biomedical applications. Nano Today 2015, 10, 631-655. [CrossRef] [PubMed]

33. Krishnamurthy, S.; Vaiyapuri, R.; Zhang, L.; Chan, J.M. Lipid-coated polymeric nanoparticles for cancer drug delivery. Biomater. Sci. 2015, 3, 923-936. [CrossRef] [PubMed]

34. Farokhzad, O.C.; Cheng, J.; Teply, B.A.; Sherifi, I.; Jon, S.; Kantoff, P.W.; Richie, J.P.; Langer, R. Targeted nanoparticle-aptamer bioconjugates for cancer chemotherapy in vivo. Proc. Natl. Acad. Sci. USA 2006, 103, 6315-6320. [CrossRef] [PubMed]

35. Abbasi, E.; Aval, S.F.; Akbarzadeh, A.; Milani, M.; Nasrabadi, H.T.; Joo, S.W.; Hanifehpour, Y.; Nejati-Koshki, K.; Pashaei-Asl, R. Dendrimers: Synthesis, applications, and properties. Nanoscale Res. Lett. 2014, 9, 247. [CrossRef]

36. Sharma, A.K.; Gothwal, A.; Kesharwani, P.; Alsaab, H.O.; Iyer, A.K.; Gupta, U. Dendrimer nanoarchitectures for cancer diagnosis and anticancer drug delivery. Drug Discov. Today 2017, 22, 314-326. [CrossRef]

37. Wu, L.; Ficker, M.; Christensen, J.B.; Trohopoulos, P.N.; Moghimi, S.M. Dendrimers in medicine: Therapeutic concepts and pharmaceutical challenges. Bioconjugate Chem. 2015, 26, 1198-1211. [CrossRef]

38. Cai, X.; Hu, J.; Xiao, J.; Cheng, Y. Dendrimer and cancer: A patent review (2006-present). Expert Opin. Ther. Patents 2013, 23, 515-529. [CrossRef]

39. Thakkar, M.; Brijesh, S. Opportunities and challenges for niosomes as drug delivery systems. Curr. Drug Deliv. 2016, 13, 1275-1289. [CrossRef]

40. Marianecci, C.; Di Marzio, L.; Rinaldi, F.; Celia, C.; Paolino, D.; Alhaique, F.; Esposito, S.; Carafa, M. Niosomes from 80s to present: The state of the art. Adv. Colloid Interface Sci. 2014, 205, 187-206. [CrossRef]

41. Pereira, M.C.; Pianella, M.; Wei, D.; Moshnikova, A.; Marianecci, C.; Carafa, M.; Andreev, O.A.; Reshetnyak, Y.K. pH-sensitive pHLIP ${ }^{\circledR}$ coated niosomes. Mol. Membr. Biol. 2016, 33, 51-63. [CrossRef] [PubMed]

42. Jaiswal, M.; Dudhe, R.; Sharma, P.K. Nanoemulsion: An advanced mode of drug delivery system. 3 Biotech 2014, 5, 123-127. [CrossRef] [PubMed]

43. Sahu, P.; Das, D.; Mishra, V.K.; Kashaw, V.; Kashaw, S.; Sahu, D.D.P. Nanoemulsion: A novel eon in cancer chemotherapy. Mini Rev. Med. Chem. 2017, 17, 1778-1792. [CrossRef] [PubMed]

44. Gorain, B.; Choudhury, H.; Nair, A.; Dubey, S.K.; Kesharwani, P. Theranostic application of nanoemulsions in chemotherapy. Drug Discov. Today 2020, 25, 1174-1188. [CrossRef] [PubMed]

45. Lu, Y.; Chen, Y.; Gemeinhart, R.A.; Wu, W.; Li, T. Developing nanocrystals for cancer treatment. Nanomedicine 2015, 10, 2537-2552. [CrossRef]

46. Jarvis, M.; Krishnan, V.; Mitragotri, S. Nanocrystals: A perspective on translational research and clinical studies. Bioeng. Transl. Med. 2018, 4, 5-16. [CrossRef]

47. Miao, X.; Yang, W.; Feng, T.; Lin, J.; Huang, P. Drug nanocrystals for cancer therapy. Wiley Interdiscip. Rev. Nanomed. Nanobiotechnol. 2017, 10, e1499. [CrossRef]

48. Lu, Y.; Li, Y.; Wu, W. Injected nanocrystals for targeted drug delivery. Acta Pharm. Sin. B 2016, 6, 106-113. [CrossRef]

49. Nishimura, Y.; Ishii, J.; Ogino, C.; Kondo, A. Genetic engineering of bio-nanoparticles for drug delivery: A review. J. Biomed. Nanotechnol. 2014, 10, 2063-2085. [CrossRef] 
50. Li, K.; Nguyen, H.G.; Lu, X.; Wang, Q. Viruses and their potential in bioimaging and biosensing applications. Analyst 2010, 135, 21-27. [CrossRef]

51. Tarhini, M.; Greige-Gerges, H.; Elaissari, A. Protein-based nanoparticles: From preparation to encapsulation of active molecules. Int. J. Pharm. 2017, 522, 172-197. [CrossRef] [PubMed]

52. Verma, D.; Gulati, N.; Kaul, S.; Mukherjee, S.; Nagaich, U. Protein based nanostructures for drug delivery. J. Pharm. 2018, 2018, 9285854. [CrossRef] [PubMed]

53. Dostalova, S.; Vasickova, K.; Hynek, D.; Krizkova, S.; Richtera, L.; Vaculovicova, M.; Eckschlager, T.; Stiborová, M.; Heger, Z.; Adam, V. Apoferritin as an ubiquitous nanocarrier with excellent shelf life. Int. J. Nanomed. 2017, 12, 2265-2278. [CrossRef] [PubMed]

54. Syn, N.L.; Ho, D.; Goh, B.C.; Wang, L.; Lim, C.T. Exosomes in cancer nanomedicine and immunotherapy: Prospects and challenges. Trends Biotechnol. 2017, 35, 665-676. [CrossRef]

55. Srinivasan, S.; Vannberg, F.O.; Dixon, J.B. Lymphatic transport of exosomes as a rapid route of information dissemination to the lymph node. Sci. Rep. 2016, 6, 24436. [CrossRef]

56. Conlan, R.S.; Pisano, S.; Oliveira, M.I.; Ferrari, M.; Pinto, I.M. Exosomes as reconfigurable therapeutic systems. Trends Mol. Med. 2017, 23, 636-650. [CrossRef] [PubMed]

57. Xu, R.; Greening, D.W.; Zhu, H.J.; Takahashi, N.; Simpson, R.J. Extracellular vesicle isolation and characterization: Toward clinical application. J. Clin. Investig. 2016, 126, 1152-1162. [CrossRef]

58. Johnsen, K.B.; Gudbergsson, J.M.; Skov, M.N.; Pilgaard, L.; Moos, T.; Duroux, M. A comprehensive overview of exosomes as drug delivery vehicles-Endogenous nanocarriers for targeted cancer therapy. Biochim. Biophys. Acta 2014, 1846, 75-87. [CrossRef]

59. Luan, X.; Sansanaphongpricha, K.; Myers, I.; Chen, H.; Yuan, H.; Sun, D. Engineering exosomes as refined biological nanoplatforms for drug delivery. Acta Pharmacol. Sin. 2017, 38, 754-763. [CrossRef]

60. Subbaiya, R.; Saravanan, M.; Priya, A.R.; Shankar, K.R.; Selvam, M.M.; Ovais, M.; Balajee, R.; Barabadi, H. Biomimetic synthesis of silver nanoparticles from Streptomyces atrovirens and their potential anticancer activity against human breast cancer cells. IET Nanobiotechnol. 2017, 11, 965-972. [CrossRef]

61. Mohammadzadeh, R. Hypothesis: Silver nanoparticles as an adjuvant for cancer therapy. Adv. Pharm. Bull. 2012, 2, 133. [CrossRef] [PubMed]

62. Xia, Y.; You, P.; Xu, F.; Liu, J.; Xing, F. Novel Functionalized selenium nanoparticles for enhanced anti-hepatocarcinoma activity in vitro. Nanoscale Res. Lett. 2015, 10, 1051. [CrossRef] [PubMed]

63. Zheng, W.; Yin, T.; Chen, Q.; Qin, X.; Huang, X.; Zhao, S.; Xu, T.; Chen, L.; Liu, J. Co-delivery of Se nanoparticles and pooled SiRNAs for overcoming drug resistance mediated by P-glycoprotein and class III $\beta$-tubulin in drug-resistant breast cancers. Acta Biomater. 2016, 31, 197-210. [CrossRef] [PubMed]

64. Li, Y.; Lin, Z.; Guo, M.; Zhao, M.; Xia, Y.; Wang, C.; Xu, T.; Zhu, B. Inhibition of H1N1 influenza virus-induced apoptosis by functionalized selenium nanoparticles with amantadine through ROS-mediated AKT signaling pathways. Int. J. Nanomed. 2018, 13, 2005-2016. [CrossRef] [PubMed]

65. Kuzyniak, W.; Adegoke, O.; Sekhosana, K.; D’Souza, S.; Tshangana, S.C.; Hoffmann, B.; Ermilov, E.A.; Nyokong, T.; Höpfner, M. Synthesis and characterization of quantum dots designed for biomedical use. Int. J. Pharm. 2014, 466, 382-389. [CrossRef] [PubMed]

66. Tang, Y.; Han, S.; Liu, H.; Chen, X.; Huang, L.; Li, X.; Zhang, J. The role of surface chemistry in determining in vivo biodistribution and toxicity of CdSe/ZnS core-shell quantum dots. Biomaterials 2013, 34, 8741-8755. [CrossRef]

67. Seifalian, A.M.; Madani, S.Y.; Naderi, N.; Dissanayake, O.; Tan, A. A new era of cancer treatment: Carbon nanotubes as drug delivery tools. Int. J. Nanomed. 2011, 6, 2963-2979. [CrossRef]

68. Ho, D.; Wang, C.H.K.; Ho, D. Nanodiamonds: The intersection of nanotechnology, drug development, and personalized medicine. Sci. Adv. 2015, 1, e1500439. [CrossRef]

69. Van Der Laan, K.; Hasani, M.; Zheng, T.; Schirhagl, R. Nanodiamonds for in vivo applications. Small 2018, 14, 1703838. [CrossRef]

70. Vinardell, M.; Mitjans, M. Antitumor activities of metal oxide nanoparticles. Nanomaterials 2015, 5, $1004-1021$. [CrossRef]

71. Li, Q.; Cai, T.G.; Huang, Y.; Xia, X.; Cole, S.; Cai, Y. A review of the structure, preparation, and application of NLCs, PNPs, and PLNs. Nanomaterials 2017, 7, 122. [CrossRef] [PubMed]

72. Huynh, N.; Passirani, C.; Saulnier, P.; Benoit, J.P. Lipid nanocapsules: A new platform for nanomedicine. Int. J. Pharm. 2009, 379, 201-209. [CrossRef] [PubMed] 
73. Moura, R.P.; Pacheco, C.; Pêgo, A.P.; Rieux, A.D.; Sarmento, B. Lipid nanocapsules to enhance drug bioavailability to the central nervous system. J. Control. Release 2020, 322, 390-400. [CrossRef] [PubMed]

74. Lu, W.; Wei, Z.; Gu, Z.-Y.; Liu, T.-F.; Park, J.; Park, J.; Tian, J.; Zhang, M.; Zhang, Q.; Iii, T.G.; et al. Tuning the structure and function of metal-organic frameworks via linker design. Chem. Soc. Rev. 2014, 43, 5561-5593. [CrossRef] [PubMed]

75. Simon-Yarza, T.; Mielcarek, A.; Couvreur, P.; Serre, C. Nanoparticles of metal-organic frameworks: On the road to in vivo efficacy in biomedicine. Adv. Mater. 2018, 30, e1707365. [CrossRef]

76. Horcajada, P.; Gref, R.; Baati, T.; Allan, P.K.; Maurin, G.; Couvreur, P.; Férey, G.; Morris, R.E.; Serre, C.; Patrick, C. Metal-organic frameworks in biomedicine. Chem. Rev. 2012, 112, 1232-1268. [CrossRef]

77. Cai, W.; Chu, C.C.; Liu, G.; Wang, Y.X. Metal-Organic framework-based nanomedicine platforms for drug delivery and molecular imaging. Small 2015, 11, 4806-4822. [CrossRef]

78. Nabholtz, J.M.; Riva, A. Taxane/anthracycline combinations: Setting a new standard in breast cancer? Oncology 2001, 6 (Suppl. 3), 5-12. [CrossRef]

79. Lee, J.J.; Yazan, L.S.; Abdullah, C.A.C. A review on current nanomaterials and their drug conjugate for targeted breast cancer treatment. Int. J. Nanomed. 2017, 12, 2373-2384. [CrossRef]

80. Smith, L.A.; Cornelius, V.R.; Plummer, C.J.; Levitt, G.; Verrill, M.; Canney, P.; Jones, A.L. Cardiotoxicity of anthracycline agents for the treatment of cancer: Systematic review and meta-analysis of randomised controlled trials. BMC Cancer 2010, 10, 337. [CrossRef]

81. Mackler, N.J.; Pienta, K.J. Drug Insight: Use of docetaxel in prostate and urothelial cancers. Nat. Clin. Pract. Urol. 2005, 2, 92-100. [CrossRef] [PubMed]

82. Van Vuuren, R.J.; Visagie, M.H.; Theron, A.E.; Joubert, A. Antimitotic drugs in the treatment of cancer. Cancer Chemother. Pharmacol. 2015, 76, 1101-1112. [CrossRef] [PubMed]

83. Gao, X.; Wang, S.; Wang, B.; Deng, S.; Liu, X.; Zhang, X.; Luo, L.; Fan, R.; Xiang, M.; You, C.; et al. Improving the anti-ovarian cancer activity of docetaxel with biodegradable self-assembly micelles through various evaluations. Biomaterials 2015, 53, 646-658. [CrossRef] [PubMed]

84. Ruttala, H.B.; Chitrapriya, N.; Kaliraj, K.; Ramasamy, T.; Shin, W.H.; Jeong, J.-H.; Kim, J.R.; Ku, S.K.; Choi, H.G.; Yong, C.S.; et al. Facile construction of bioreducible crosslinked polypeptide micelles for enhanced cancer combination therapy. Acta Biomater. 2017, 63, 135-149. [CrossRef]

85. Zhang, L.; Zhang, N. How nanotechnology can enhance docetaxel therapy. Int. J. Nanomed. 2013, 8, $2927-2941$. [CrossRef] [PubMed]

86. Robinson, K.; Lambiase, L.; Li, J.; Monteiro, C.; Schiff, M. Case report: Fatal cholestatic liver failure associated with gemcitabine therapy. Dig. Dis. Sci. 2003, 48, 1804-1808. [CrossRef]

87. Chen, Y.W.; Liu, J.Y.; Lin, S.T.; Li, J.M.; Huang, S.H.; Chen, J.Y.; Wu, J.Y.; Kuo, C.C.; Wu, C.L.; Lu, Y.C.; et al. Proteomic analysis of gemcitabine-induced drug resistance in pancreatic cancer cells. Mol. BioSyst. 2011, 7, 3065-3074. [CrossRef]

88. Brandes, A.A.; Bartolotti, M.; Tosoni, A.; Franceschi, E. Nitrosoureas in the management of malignant gliomas. Curr. Neurol. Neurosci. Rep. 2016, 16, 13. [CrossRef]

89. Akiyama, Y.; Kimura, Y.; Enatsu, R.; Mikami, T.; Wanibuchi, M.; Mikuni, N. Advantages and disadvantages of combined chemotherapy with carmustine wafer and bevacizumab in patients with newly diagnosed glioblastoma: A single-institutional experience. World Neurosurg. 2018, 113, e508-e514. [CrossRef]

90. Vilar, G.; Tulla-Puche, J.; Albericio, F. Polymers and drug delivery systems. Curr. Drug Deliv. 2012, 9, 367-394. [CrossRef]

91. Guo, S.; Vieweger, M.; Zhang, K.; Yin, H.; Wang, H.; Li, X.; Li, S.; Hu, S.; Sparreboom, A.; Evers, B.M.; et al. Ultra-thermostable RNA nanoparticles for solubilizing and high-yield loading of paclitaxel for breast cancer therapy. Nat. Commun. 2020, 11, 972. [CrossRef] [PubMed]

92. Kaminskas, L.M.; Kelly, B.D.; McLeod, V.M.; Sberna, G.; Owen, D.J.; Boyd, B.; Porter, C.J. Characterisation and tumour targeting of PEGylated polylysine dendrimers bearing doxorubicin via a pH labile linker. J. Control. Release 2011, 152, 241-248. [CrossRef] [PubMed]

93. Zhong, Q.; Da Rocha, S.R. Poly(amidoamine) dendrimer-doxorubicin conjugates: In vitro characteristics and pseudosolution formulation in pressurized metered-dose inhalers. Mol. Pharm. 2016, 13, 1058-1072. [CrossRef] [PubMed] 
94. Park, K.; Lee, G.Y.; Kim, Y.S.; Yu, M.; Park, R.W.; Kim, I.S.; Kim, S.Y.; Byun, Y. Heparin-deoxycholic acid chemical conjugate as an anticancer drug carrier and its antitumor activity. J. Control. Release 2006, 114, 300-306. [CrossRef]

95. Choudhary, S.; Gupta, L.; Rani, S.; Dave, K.; Gupta, U. Impact of dendrimers on solubility of hydrophobic drug molecules. Front. Pharmacol. 2017, 8, 261. [CrossRef]

96. Kim, M.S.; Haney, M.J.; Zhao, Y.; Mahajan, V.; Deygen, I.; Klyachko, N.L.; Inskoe, E.; Piroyan, A.; Sokolsky, M.; Okolie, O.; et al. Development of exosome-encapsulated paclitaxel to overcome MDR in cancer cells. Nanomedicine 2016, 12, 655-664. [CrossRef]

97. Iannazzo, D.; Pistone, A.; Salamò, M.; Galvagno, S.; Romeo, R.; Giofré, S.V.; Branca, C.; Visalli, G.; Di Pietro, A. Graphene quantum dots for cancer targeted drug delivery. Int. J. Pharm. 2017, 518, 185-192. [CrossRef]

98. Zhao, D.; Wu, J.; Li, C.; Zhang, H.; Li, Z.; Luan, Y. Precise ratiometric loading of PTX and DOX based on redox-sensitive mixed micelles for cancer therapy. Colloids Surf. B Biointerfaces 2017, 155, 51-60. [CrossRef]

99. Xie, H.J.; Zhao, J.; Zhuo-Ma, D.; Zhan-Dui, N.; Er-Bu, A.; Tsering, T. Inhibiting tumour metastasis by DQA modified paclitaxel plus ligustrazine micelles in treatment of non-small-cell lung cancer. Artif. Cells Nanomed. Biotechnol. 2019, 47, 3465-3477. [CrossRef]

100. Zou, J.; Su, S.; Chen, Z.; Liang, F.; Zeng, Y.; Cen, W.; Zhang, X.; Xia, Y.; Huang, D. Hyaluronic acid-modified selenium nanoparticles for enhancing the therapeutic efficacy of paclitaxel in lung cancer therapy. Artif. Cells Nanomed. Biotechnol. 2019, 47, 3456-3464. [CrossRef]

101. Wu, P.; Yin, D.; Liu, J.; Zhou, H.; Guo, M.; Liu, J.; Liu, Y.; Zheng, H.; Liu, Y.; Chen, C. Cell membrane based biomimetic nanocomposites for targeted therapy of drug resistant EGFR-mutated lung cancer. Nanoscale 2019, 11, 19520-19528. [CrossRef] [PubMed]

102. Huang, X.; Wan, J.; Leng, D.; Zhang, Y.; Yang, S. Dual-targeting nanomicelles with CD133 and CD44 aptamers for enhanced delivery of gefitinib to two populations of lung cancer-initiating cells. Exp. Ther. Med. 2019, 19, 192-204. [CrossRef]

103. Zhang, Z.; Cheng, W.; Pan, Y.; Jia, L. An anticancer agent-loaded PLGA nanomedicine with glutathione-response and targeted delivery for the treatment of lung cancer. J. Mater. Chem. B 2020, 8, 655-665. [CrossRef] [PubMed]

104. He, W.; Xiao, W.; Zhang, X.; Sun, Y.; Chen, Y.; Chen, Q.; Fang, X.; Du, S.; Sha, X. Pulmonary-affinity paclitaxel polymer micelles in response to biological functions of ambroxol enhance therapeutic effect on lung cancer. Int. J. Nanomed. 2020, 15, 779-793. [CrossRef] [PubMed]

105. Liang, Y.; Zhang, J.; Tian, B.; Wu, Z.; Svirskis, D.; Han, J.T. A NAG-guided nano-delivery system for redoxand ph-triggered intracellularly sequential drug release in cancer cells. Int. J. Nanomed. 2020, 15, 841-855. [CrossRef] [PubMed]

106. Zhang, H.; Hu, H.; Zhang, H.; Dai, W.; Wang, X.; Wang, X.; Zhang, Q. Effects of PEGylated paclitaxel nanocrystals on breast cancer and its lung metastasis. Nanoscale 2015, 7, 10790-10800. [CrossRef] [PubMed]

107. Guvena, A.; Villaresbc, G.J.; Hilsenbeck, S.G.; Lewisb, A.; Landua, J.D.; Dobrolecki, L.E.; Wilson, L.J.; Lewis, M.T. Carbon nanotube capsules enhance the in vivo efficacy of cisplatin. Acta Biomater. 2017, 58, 466-478. [CrossRef]

108. Li, J.; Xu, W.; Yuan, X.; Chen, H.; Song, H.; Wang, B.; Han, J. Polymer-lipid hybrid anti-HER2 nanoparticles for targeted salinomycin delivery to HER2-positive breast cancer stem cells and cancer cells. Int. J. Nanomed. 2017, 12, 6909-6921. [CrossRef]

109. Le, D.H.T.; Lee, K.L.; Shukla, S.; Commandeur, U.; Steinmetz, N.F. Potato virus X, a filamentous plant viral nanoparticle for doxorubicin delivery in cancer therapy. Nanoscale 2017, 9, 2348-2357. [CrossRef]

110. Jiang, S.; Hua, L.; Guo, Z.; Sun, L. One-pot green synthesis of doxorubicin loaded-silica nanoparticles for in vivo cancer therapy. Mater. Sci. Eng. C 2018, 90, 257-263. [CrossRef]

111. Zheng, G.; Zheng, M.; Yang, B.; Fu, H.; Li, Y. Improving breast cancer therapy using doxorubicin loaded solid lipid nanoparticles: Synthesis of a novel arginine-glycine-aspartic tripeptide conjugated, $\mathrm{pH}$ sensitive lipid and evaluation of the nanomedicine in vitro and in vivo. Biomed. Pharmacother. 2019, 116, 109006. [CrossRef] [PubMed]

112. Fang, H.; Zhao, X.; Gu, X.; Sun, H.; Cheng, R.; Zhong, Z.; Deng, C. CD44-targeted multifunctional nanomedicines based on a single-component hyaluronic acid conjugate with all-natural precursors: Construction and treatment of metastatic breast tumors in vivo. Biomacromolecules 2020, 21, 104-113. [CrossRef] [PubMed] 
113. Li, Y.; Li, X.; Lu, Y.; Chaurasiya, B.; Mi, G.; Shi, D.; Chen, D.; Webster, T.J.; Tu, J.; Shen, Y. Co-delivery of Poria cocos extract and doxorubicin as an 'all-in-one' nanocarrier to combat breast cancer multidrug resistance during chemotherapy. Nanomedicine 2019, 23, 102095. [CrossRef]

114. Lei, J.; Wang, H.; Zhu, D.; Wan, Y.; Yin, L. Combined effects of avasimibe immunotherapy, doxorubicin chemotherapy, and metal-organic frameworks nanoparticles on breast cancer. J. Cell. Physiol. 2019, 235, 4814-4823. [CrossRef] [PubMed]

115. Dancy, J.G.; Wadajkar, A.S.; Connolly, N.P.; Galisteo, R.; Ames, H.M.; Peng, S.; Tran, N.L.; Goloubeva, O.G.; Woodworth, G.F.; Winkles, J.A.; et al. Decreased nonspecific adhesivity, receptor-targeted therapeutic nanoparticles for primary and metastatic breast cancer. Sci. Adv. 2020, 6, eaax3931. [CrossRef]

116. Han, B.; Yang, Y.; Chen, J.; Tang, H.; Sun, Y.; Zhang, Z.; Wang, Z.; Li, Y.; Li, Y.; Luan, X.; et al. Preparation, characterization, and pharmacokinetic study of a novel long-acting targeted paclitaxel liposome with antitumor activity. Int. J. Nanomed. 2020, 15, 553-571. [CrossRef]

117. Zafar, S.; Akhter, S.; Garg, N.; Selvapandiyan, A.; Jain, G.K.; Ahmad, F.J. Co-encapsulation of docetaxel and thymoquinone in mPEG-DSPE-vitamin E TPGS-lipid nanocapsules for breast cancer therapy: Formulation optimization and implications on cellular and in vivo toxicity. Eur. J. Pharm. Biopharm. 2020, 148, 10-26. [CrossRef]

118. Xu, C.; Xu, J.; Zheng, Y.; Fang, Q.; Lv, X.; Wang, X.; Cheng, X. Active-targeting and acid-sensitive pluronic prodrug micelles for efficiently overcoming MDR in breast cancer. J. Mater. Chem. B 2020, 8, 2726-2737. [CrossRef]

119. Teijeiro-Valiño, C.; Novoa-Carballal, R.; Borrajo, E.; Vidal, A.; Alonso-Nocelo, M.; Freire, M.D.L.F.; López-Casas, P.P.; Hidalgo, M.; Csaba, N.; Alonso, M.J. A multifunctional drug nanocarrier for efficient anticancer therapy. J. Control. Release 2019, 294, 154-164. [CrossRef]

120. Lin, C.; Hu, Z.; Yuan, G.; Su, H.; Zeng, Y.; Guo, Z.; Zhong, F.; Jiang, K.; He, S.; Songqing, H. HIF1 $\alpha$-siRNA and gemcitabine combination-based GE-11 peptide antibody-targeted nanomedicine for enhanced therapeutic efficacy in pancreatic cancers. J. Drug Target. 2019, 27, 797-805. [CrossRef]

121. Madamsetty, V.S.; Sharma, A.; Toma, M.; Samaniego, S.; Gallud, A.; Wang, E.; Pal, K.; Mukhopadhyay, D.; Fadeel, B. Tumor selective uptake of drug-nanodiamond complexes improves therapeutic outcome in pancreatic cancer. Nanomedicine 2019, 18, 112-121. [CrossRef] [PubMed]

122. Massey, A.E.; Sikander, M.; Chauhan, N.; Kumari, S.; Setua, S.; Shetty, A.B.; Mandil, H.; Kashyap, V.K.; Khan, S.; Jaggi, M.; et al. Next-generation paclitaxel-nanoparticle formulation for pancreatic cancer treatment. Nanomedicine 2019, 20, 102027. [CrossRef] [PubMed]

123. Madamsetty, V.S.; Pal, K.; Keshavan, S.; Caulfield, T.R.; Dutta, S.K.; Wang, E.; Fadeel, B.; Mukhopadhyay, D. Development of multi-drug loaded PEGylated nanodiamonds to inhibit tumor growth and metastasis in genetically engineered mouse models of pancreatic cancer. Nanoscale 2019, 11, 22006-22018. [CrossRef]

124. Sun, J.; Wan, Z.; Chen, Y.; Xu, J.; Luo, Z.; Parise, R.A.; Diao, D.; Ren, P.; Beumer, J.H.; Lu, B.; et al. Triple drugs co-delivered by a small gemcitabine-based carrier for pancreatic cancer immunochemotherapy. Acta Biomater. 2020, 106, 289-300. [CrossRef]

125. Etman, S.M.; Abdallah, O.Y.; Mehanna, R.A.; Elnaggar, Y.S. Lactoferrin/Hyaluronic acid double-coated lignosulfonate nanoparticles of quinacrine as a controlled release biodegradable nanomedicine targeting pancreatic cancer. Int. J. Pharm. 2020, 578, 119097. [CrossRef] [PubMed]

126. Elechalawar, C.K.; Hossen, N.; Shankarappa, P.; Peer, C.J.; Figg, W.D.; Robertson, J.D.; Bhattacharya, R.; Mukherjee, P. Targeting pancreatic cancer cells and stellate cells using designer nanotherapeutics in vitro. Int. J. Nanomed. 2020, 15, 991-1003. [CrossRef]

127. Han, H.; Hou, Y.; Chen, X.; Zhang, P.; Kang, M.; Jin, Q.; Ji, J.; Gao, M. Metformin-induced stromal depletion to enhance the penetration of gemcitabine-loaded magnetic nanoparticles for pancreatic cancer targeted therapy. J. Am. Chem. Soc. 2020, 142, 4944-4954. [CrossRef]

128. Zhai, M.; Wang, Y.; Zhang, L.; Liang, M.; Fu, S.; Cui, L.; Yang, M.; Gong, W.; Li, Z.; Yu, L.; et al. Glioma targeting peptide modified apoferritin nanocage. Drug Deliv. 2018, 25, 1013-1024. [CrossRef]

129. Guo, X.; Wu, G.; Wang, H.; Chen, L. Pep-1\&borneol-bifunctionalized carmustine-loaded micelles enhance anti-glioma efficacy through tumor-targeting and BBB-penetrating. J. Pharm. Sci. 2019, 108, 1726-1735. [CrossRef] 
130. Zou, Y.; Liu, Y.; Yang, Z.; Zhang, D.; Lu, Y.; Zheng, M.; Xue, X.; Geng, J.; Chung, R.S.; Shi, B. Effective and targeted human orthotopic glioblastoma xenograft therapy via a multifunctional biomimetic nanomedicine. Adv. Mater. 2018, 30, e1803717. [CrossRef]

131. Meng, L.; Chu, X.; Xing, H.; Liu, X.; Xin, X.; Chen, L.; Jin, M.; Guan, Y.; Huang, W.; Gao, Z. Improving glioblastoma therapeutic outcomes via doxorubicin-loaded nanomicelles modified with borneol. Int. J. Pharm. 2019, 567, 118485. [CrossRef] [PubMed]

132. Wang, H.; Zhu, Z.; Zhang, G.; Lin, F.; Liu, Y.; Zhang, Y.; Feng, J.; Chen, W.; Meng, Q.; Chen, L. AS1411 aptamer/hyaluronic acid-bifunctionalized microemulsion co-loading shikonin and docetaxel for enhanced antiglioma therapy. J. Pharm. Sci. 2019, 108, 3684-3694. [CrossRef] [PubMed]

133. Younis, M.; Faming, W.; HongYan, Z.; Mengmeng, T.; Hang, S.; Yuan, L. Iguratimod encapsulated PLGA-NPs improves therapeutic outcome in glioma, glioma stem-like cells and temozolomide resistant glioma cells. Nanomedicine 2019, 22, 102101. [CrossRef]

134. Toktas, S.; Sahin, A.; Lule, S.; Esendagli, G.; Vural, I.; Oguz, K.K.; Söylemezoğlu, F.; Mut, M.; Dalkara, T.; Khan, M.A.; et al. Combination of Paclitaxel and R-flurbiprofen loaded PLGA nanoparticles suppresses glioblastoma growth on systemic administration. Int. J. Pharm. 2020, 578, 119076. [CrossRef] [PubMed]

135. Zhang, Y.; Shen, Y.; Liao, M.M.; Mao, X.; Mi, G.J.; You, C.; Guo, Q.; Li, W.J.; Wang, X.Y.; Lin, N.; et al. Galactosylated chitosan triptolide nanoparticles for overcoming hepatocellular carcinoma: Enhanced therapeutic efficacy, low toxicity, and validated network regulatory mechanisms. Nanomedicine 2019, 15, 86-97. [CrossRef] [PubMed]

136. Yao, Y.; Wang, T.; Liu, Y.; Zhang, N. Co-delivery of sorafenib and VEGF-siRNA via pH-sensitive liposomes for the synergistic treatment of hepatocellular carcinoma. Artif. Cells Nanomed. Biotechnol. 2019, 47, 1374-1383. [CrossRef]

137. Han, W.; Shi, L.; Xie, B.; Wan, J.; Ren, L.; Wang, Y.; Chen, X.; Wang, H. Supramolecular engineering of molecular inhibitors in an adaptive cytotoxic nanoparticle for synergistic cancer therapy. ACS Appl. Mater. Interfaces 2019, 12, 1707-1720. [CrossRef]

138. Zhang, F.; Jia, Y.; Zheng, X.; Shao, D.; Zhao, Y.; Wang, Z.; Dawulieti, J.; Liu, W.; Sun, M.; Sun, W.; et al. Janus nanocarrier-based co-delivery of doxorubicin and berberine weakens chemotherapy-exacerbated hepatocellular carcinoma recurrence. Acta Biomater. 2019, 100, 352-364. [CrossRef]

139. Xu, Y.; Kong, Y.; Xu, J.; Li, X.; Gou, X.J.; Yin, T.; He, B.H.; Zhang, Y.; Tang, X. Doxorubicin intercalated copper diethyldithiocarbamate functionalized layered double hydroxide hybrid nanoparticles for targeted therapy of hepatocellular carcinoma. Biomater. Sci. 2020, 8, 897-911. [CrossRef]

140. Tang, Z.; Luo, C.; Jun, Y.; Yao, M.; Zhang, M.; He, K.; Jin, L.; Ma, J.; Chen, S.; Sun, S.; et al. Nanovector assembled from natural egg yolk lipids for tumor-targeted delivery of therapeutics. ACS Appl. Mater. Interfaces 2020, 12, 7984-7994. [CrossRef]

141. Hefnawy, A.; Khalil, I.A.H.; Arafa, K.; Emara, M.; El-Sherbiny, I.M. Dual-ligand functionalized core-shell chitosan-based nanocarrier for hepatocellular carcinoma-targeted drug delivery. Int. J. Nanomed. 2020, 15, 821-837. [CrossRef]

142. Böluükbas, D.A.; Meiners, S. Lung cancer nanomedicine: Potentials and pitfalls. Nanomedicine 2015, 10, 3203-3212. [CrossRef]

143. Castellanos, E.H.; Horn, L. Immunotherapy in lung cancer. Cancer Treat. Res. 2016, 170, 203-223. [CrossRef]

144. Rotow, J.; Bivona, T.G. Understanding and targeting resistance mechanisms in NSCLC. Nat. Rev. Cancer 2017, 17, 637-658. [CrossRef] [PubMed]

145. Kandoth, C.; McLellan, M.D.; Vandin, F.; Ye, K.; Niu, B.; Lu, C.; Xie, M.; Zhang, Q.; McMichael, J.F.; Wyczalkowski, M.A.; et al. Mutational landscape and significance across 12 major cancer types. Nature 2013, 502, 333-339. [CrossRef]

146. Mohamed, N.K.; Hamad, M.A.; Hafez, M.Z.E.; Wooley, K.L.; Elsabahy, M. Nanomedicine in management of hepatocellular carcinoma: Challenges and opportunities. Int. J. Cancer 2016, 140, 1475-1484. [CrossRef]

147. Lin, T.; Yuan, A.; Zhao, X.; Lian, H.; Zhuang, J.; Zhang, Q.; Liu, G.; Zhang, S.; Chen, W.; Cao, W.; et al. Self-assembled tumor-targeting hyaluronic acid nanoparticles for photothermal ablation in orthotopic bladder cancer. Acta Biomater. 2017, 53, 427-438. [CrossRef]

148. Kumar, P.; Tambe, P.; Paknikar, K.M.; Gajbhiye, V. Folate/ N -acetyl glucosamine conjugated mesoporous silica nanoparticles for targeting breast cancer cells: A comparative study. Colloids Surf. B Biointerfaces 2017, 156, 203-212. [CrossRef] 
149. Leung, E.L.H.; Fiscus, R.R.; Tung, J.W.; Tin, V.P.-C.; Cheng, L.C.; Sihoe, A.D.L.; Fink, L.M.; Ma, Y.; Wong, M.P. Non-small cell lung cancer cells expressing CD44 are enriched for stem cell-like properties. PLoS ONE 2010, 5, e14062. [CrossRef]

150. Nathan, N.; Taytard, J.; Duquesnoy, P.; Thouvenin, G.; Corvol, H.; Amselem, S.; Clement, A. Surfactant protein A: A key player in lung homeostasis. Int. J. Biochem. Cell Biol. 2016, 81, 151-155. [CrossRef]

151. Mitsuhashi, A.; Goto, H.; Kuramoto, T.; Tabata, S.; Yukishige, S.; Abe, S.; Hanibuchi, M.; Kakiuchi, S.; Saijo, A.; Aono, Y.; et al. Surfactant protein A suppresses lung cancer progression by regulating the polarization of tumor-associated macrophages. Am. J. Pathol. 2013, 182, 1843-1853. [CrossRef]

152. Chang, L.C.; Chang, Y.Y.; Gau, C.S. Interfacial properties of Pluronics and the interactions between Pluronics and cholesterol/DPPC mixed monolayers. J. Colloid Interface Sci. 2008, 322, 263-273. [CrossRef]

153. Chen, W.; Zheng, R.; Baade, P.D.; Zhang, S.; Zeng, H.; Bray, F.; Jemal, A.; Yu, X.Q.; He, J. Cancer statistics in China, 2015. CA Cancer J. Clin. 2016, 66, 115-132. [CrossRef]

154. Nurgalieva, Z.; Liu, C.C.; Du, X.L. Chemotherapy use and risk of bone marrow suppression in a large population-based cohort of older women with breast and ovarian cancer. Med. Oncol. 2010, 28, 716-725. [CrossRef]

155. Singh, S.K.; Singh, S.; Jr, J.W.L.; Singh, R. Drug delivery approaches for breast cancer. Int. J. Nanomed. 2017, 12, 6205-6218. [CrossRef] [PubMed]

156. Weber, P.; Wagner, M.; Schneckenburger, H. Cholesterol dependent uptake and interaction of doxorubicin in MCF-7 breast cancer cells. Int. J. Mol. Sci. 2013, 14, 8358-8366. [CrossRef]

157. Dou, X.Q.; Wang, H.; Zhang, J.; Wang, F.; Xu, G.L.; Xu, C.C.; Xu, H.H.; Xiang, S.S.; Fu, J.; Song, H.F. Aptamer-drug conjugate: Targeted delivery of doxorubicin in a HER3 aptamer-functionalized liposomal delivery system reduces cardiotoxicity. Int. J. Nanomed. 2018, 13, 763-776. [CrossRef]

158. Zhang, H.; Gong, J.; Zhang, H.; Kong, D. Induction of apoptosis and reversal of permeability glycoprotein-mediated multidrug resistance of MCF-7/ADM by ginsenoside Rh2. Int. J. Clin. Exp. Pathol. 2015, 8, 4444-4456.

159. Prieto-Vila, M.; Takahashi, R.U.; Usuba, W.; Kohama, I.; Ochiya, T. Drug resistance driven by cancer stem cells and their niche. Int. J. Mol. Sci. 2017, 18, 2574. [CrossRef]

160. He, L.; Gu, J.; Lim, L.Y.; Yuan, Z.X.; Mo, J. Nanomedicine-mediated therapies to target breast cancer stem cells. Front. Pharmacol. 2016, 7, 313. [CrossRef]

161. Pindiprolu, S.K.S.S.; Krishnamurthy, P.T.; Chintamaneni, P.K.; Karri, V.V.S.R. Nanocarrier based approaches for targeting breast cancer stem cells. Artif. Cells Nanomed. Biotechnol. 2017, 46, 885-898. [CrossRef] [PubMed]

162. Afzal, M.; Alharbi, K.S.; Alruwaili, N.K.; Al-Abassi, F.A.; Al-Malki, A.A.L.; Kazmi, I.; Kumar, V.; Kamal, M.A.; Nadeem, M.S.; Aslam, M.; et al. Nanomedicine in treatment of breast cancer-A challenge to conventional therapy. Semin. Cancer Biol. 2019. [CrossRef] [PubMed]

163. Sheikh, U.N.; Cohen, C.; Siddiqui, M.T. Folate receptor alpha immunohistochemistry in cytology specimens of metastatic breast carcinoma. Acta Cytol. 2015, 59, 298-304. [CrossRef]

164. Allahverdiyev, A.M.; Parlar, E.; Dinparvar, S.; Bagirova, M.; Abamor, E. Şefik Current aspects in treatment of breast cancer based of nanodrug delivery systems and future prospects. Artif. Cells Nanomed. Biotechnol. 2018, 46, S755-S762. [CrossRef]

165. Wu, D.; Si, M.; Xue, H.Y.; Wong, H.L. Nanomedicine applications in the treatment of breast cancer: Current state of the art. Int. J. Nanomed. 2017, 12, 5879-5892. [CrossRef]

166. Tran, N.L.; McDonough, W.S.; Savitch, B.A.; Fortin, S.P.; Winkles, J.A.; Symons, M.; Nakada, M.; Cunliffe, H.E.; Hostetter, G.; Hoelzinger, D.B.; et al. Increased fibroblast growth factor-inducible 14 expression levels promote glioma cell invasion via rac1 and nuclear factor- B and correlate with poor patient outcome. Cancer Res. 2006, 66, 9535-9542. [CrossRef]

167. Krishna, B.M.; Chaudhary, S.; Mishra, D.R.; Naik, S.K.; Suklabaidya, S.; Adhya, A.K.; Mishra, S.K. Estrogen receptor $\alpha$ dependent regulation of estrogen related receptor $\beta$ and its role in cell cycle in breast cancer. BMC Cancer 2018, 18, 607. [CrossRef]

168. Mattheolabakis, G.; Milane, L.; Singh, A.; Amiji, M. Hyaluronic acid targeting of CD44 for cancer therapy: From receptor biology to nanomedicine. J. Drug Target. 2015, 23, 605-618. [CrossRef]

169. Zhao, P.; Lu, Y.; Jiang, X.; Li, X. Clinicopathological significance and prognostic value of CD133 expression in triple-negative breast carcinoma. Cancer Sci. 2011, 102, 1107-1111. [CrossRef] 
170. Tang, X.; Loc, W.S.; Dong, C.; Matters, G.L.; Butler, P.J.; Kester, M.; Meyers, C.; Jiang, Y.; Adair, J.H. The use of nanoparticulates to treat breast cancer. Nanomedicine 2017, 12, 2367-2388. [CrossRef]

171. Rahib, L.; Smith, B.D.; Aizenberg, R.; Rosenzweig, A.B.; Fleshman, J.M.; Matrisian, L. Projecting cancer incidence and deaths to 2030: The unexpected burden of thyroid, liver, and pancreas cancers in the United States. Cancer Res. 2014, 74, 2913-2921. [CrossRef] [PubMed]

172. Li, Y.J.; Wu, J.Y.; Wang, J.M.; Xiang, D.X. Emerging nanomedicine-based strategies for preventing metastasis of pancreatic cancer. J. Control. Release 2020, 320, 105-111. [CrossRef] [PubMed]

173. Aslan, M.; Shahbazi, R.; Ulubayram, K.; Ozpolat, B. Targeted therapies for pancreatic cancer and hurdles ahead. Anticancer Res. 2018, 38, 6591-6606. [CrossRef] [PubMed]

174. Manzur, A.; Oluwasanmi, A.; Moss, D.M.; Curtis, A.D.; Hoskins, C. Nanotechnologies in pancreatic cancer therapy. Pharmaceutics 2017, 9, 39. [CrossRef]

175. Jeong, S.M.; Hwang, S.; Seong, R.H. Transferrin receptor regulates pancreatic cancer growth by modulating mitochondrial respiration and ROS generation. Biochem. Biophys. Res. Commun. 2016, 471, 373-379. [CrossRef]

176. Cai, L.; Michelakos, T.; Ferrone, C.R.; Zhang, L.; Deshpande, V.; Shen, Q.; DeLeo, A.; Yamada, T.; Zhang, G.; Ferrone, S.; et al. Expression status of folate receptor alpha is a predictor of survival in pancreatic ductal adenocarcinoma. Oncotarget 2017, 8, 37646-37656. [CrossRef]

177. Martin, L.K.; Li, X.; Kleiber, B.; Ellison, E.C.; Bloomston, M.; Zalupski, M.; Bekaii-Saab, T. VEGF remains an interesting target in advanced pancreas cancer (APCA): Results of a multi-institutional phase II study of bevacizumab, gemcitabine, and infusional 5-fluorouracil in patients with APCA. Ann. Oncol. 2012, 23, 2812-2820. [CrossRef]

178. Khare, V.; Alam, N.; Saneja, A.; Dubey, R.D.; Gupta, P.N. Targeted drug delivery systems for pancreatic cancer. J. Biomed. Nanotechnol. 2014, 10, 3462-3482. [CrossRef]

179. Kreuter, J. Drug delivery to the central nervous system by polymeric nanoparticles: What do we know? Adv. Drug Deliv. Rev. 2014, 71, 2-14. [CrossRef]

180. Kmieć, Z. Cooperation of liver cells in health and disease. Adv. Anat. Embryol. Cell Biol. 2001, 161, 1-151. [CrossRef]

181. Hare, J.I.; Lammers, T.; Ashford, M.B.; Puri, S.; Storm, G.; Barry, S.T. Challenges and strategies in anti-cancer nanomedicine development: An industry perspective. Adv. Drug Deliv. Rev. 2017, 108, 25-38. [CrossRef]

182. Wang-Gillam, A.; Li, C.P.; Bodoky, G.; Dean, A.; Shan, Y.S.; Jameson, G.; Macarulla, T.; Lee, K.H.; Cunningham, D.; Blanc, J.F.; et al. Nanoliposomal irinotecan with fluorouracil and folinic acid in metastatic pancreatic cancer after previous gemcitabine-based therapy (NAPOLI-1): A global, randomised, open-label, phase 3 trial. Lancet 2016, 387, 545-557. [CrossRef]

183. O'Sullivan, H.; Collins, D.; O’Reilly, S.; Aktas, B.Y.; Taban, H.; Aksoy, S.; Schmid, P.; Chui, S.Y.; Emens, L.A.; Altundag, K. Atezolizumab and nab-paclitaxel in advanced triple-negative breast cancer. N. Engl. J. Med. 2019, 380, 986. [CrossRef]

184. Fornaguera, C.; Solans, C. Methods for the in vitro characterization of nanomedicines-Biological component interaction. J. Pers. Med. 2017, 7, 2. [CrossRef] [PubMed]

185. Rudokas, M.; Najlah, M.; Alhnan, M.A.; Elhissi, A.M.A. Liposome delivery systems for inhalation: A critical review highlighting formulation issues and anticancer applications. Med. Princ. Pract. 2016, 25 (Suppl. 2), 60-72. [CrossRef]

186. Saptarshi, S.R.; Duschl, A.; Lopata, A.L. Interaction of nanoparticles with proteins: Relation to bio-reactivity of the nanoparticle. J. Nanobiotechnol. 2013, 11, 26. [CrossRef]

187. Mitragotri, S.; Anderson, D.G.; Chen, X.; Ho, D.; Ho, D.; Kabanov, A.V.; Karp, J.M.; Kataoka, K.; Mirkin, C.A.; Petrosko, S.H.; et al. Accelerating the translation of nanomaterials in biomedicine. ACS Nano 2015, 9, 6644-6654. [CrossRef]

188. Ragelle, H.; Danhier, F.; Préat, V.; Langer, R.; Anderson, D.G. Nanoparticle-based drug delivery systems: A commercial and regulatory outlook as the field matures. Expert Opin. Drug Deliv. 2017, 14, 851-864. [CrossRef]

(C) 2020 by the authors. Licensee MDPI, Basel, Switzerland. This article is an open access article distributed under the terms and conditions of the Creative Commons Attribution (CC BY) license (http://creativecommons.org/licenses/by/4.0/). 